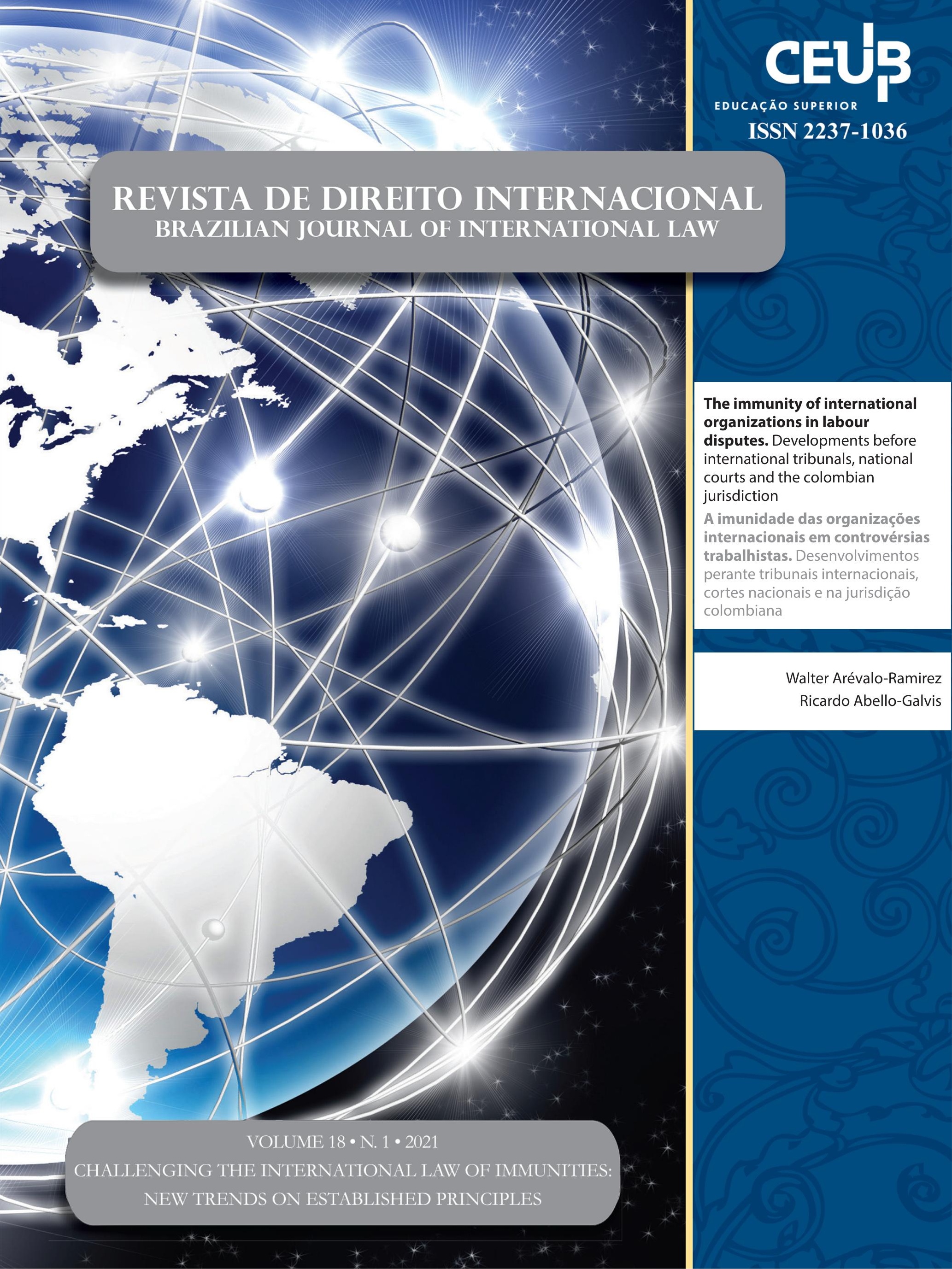


EDITORIAL

Challenging the International Law of Immunities: New Trends on Established Principles? An introduction to the special issue ............................................ 14

Lucas Carlos Lima, Loris Marotti e Paolo Palchetti

CrôniCAS........................................................................................ 17

RESPONSABILIDADE E IMUNIDADE DAS ORgANIZAÇÕES INTERNACIONAIS: PRÁTICA E DESAFIOS ...19 Vinícius Fox Drummond Cançado Trindade

The JURISDiCTIONAL IMMUNITY OF INTERNATIONAL ORgaNiZATIONS BEFORE THE BRAZILIAN SuPREMe Federal Court.

Bárbara Tuyama Sollero

The Law of State Immunity before the Brazilian Supreme Court: what is at stake WITH THE "ChANGRI-LA" CASE?

Aziz Tuffi Saliba e Lucas Carlos Lima

\section{Dossiê: Challenging the International Law of Immunities: New Trends} on Established Principles?

State Immunity and the Rights of Employees: Lights and Shadows of the Strasbourg COURT's JURISPRUdENCE .61

Pierfrancesco Rossi

A human Rights-BASEd CHALlENGE: THE KEY TO UNLOCK THE UN'S IMMUNiTY PROBLEM?...79 Héloïse Guichardaz

IMMUNITIES OF STATE OFFICIALS AND THE "FUNDAMENTALLY DIFFERENT NATURE" OF INTERNATIONAL COURTS: THE APPEALS CHAMBER DECISION IN THE JORDAN REFERRAL RE AL BASHIR ...97 Rita Guerreiro Teixeira e Hannes Verheyden 
IMUNIDADE DE JURISDIÇÃo dOS EsTADOS: O CAMINHO PARA A RELATIVIZAÇÃo

Vinícius Assis da Silveira, Luiz Felipe Costa Santana e Valesca Raizer Borges Moschen

The IMmUNity OF INTERNATIONAL ORganizations IN LABOUR DispUTES. DeVElopments BEFORE INTERNATIONAL TRIBUNALS, NATIONAL COURTS AND THE COLOMBIAN JURISDICTION ..... 137 Walter Arévalo-Ramirez e Ricardo Abello-Galvis

Imunidade de Jurisdição dos Estados E Poder Executivo brasileiro: os Pareceres dos CONSULTORES JURÍDICOS DO ITAMARATY

George Rodrigo Bandeira Galindo

Artigos SOBRe outros temas

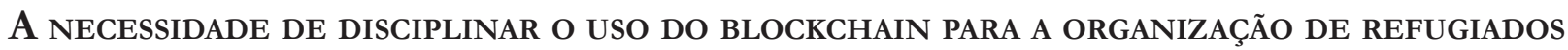
PELO DIREITO INTERNACIONAL. 195

Agatha Gonçalves Santana, Carla Noura Teixeira e Otavio Noura Teixeira

O TRABALHO INFANTIL DE MIGRANTES E REFUgIADOS VENEZUELANOS NO BRASIL

André Viana Custódio e ohana Cabral

THE NEW BRAZILIAN ANTI-TRAFFICKING LAW: CHALLENGES AND OPPORTUNITIES TO COVER THE NORMATIVE LACK . 243 Waldimeiry Correa da Silva

¿SON PARTE DEL BLOQUE DE CONSTITUCIONALIDAD LOS TRATADOS INTERNACIONALES DE DERECHOS HuMANOS DE LA OEA EN CHILE?: AVANCES EN BASE A LA DOCTRINA, NORMATIVA Y JURISPRUDÊNCIA. 270

Juan Pablo Díaz Fuenzalida

O Tratado de Saint-Germain-En-Laye e os Efeitos do instituto da “opÇão” Sobre a CONDIÇÃO JURÍDICA DOS DESCENDENTES DE CIDADÃOS AUSTRÍACOS TRENTINO-TIROLÊSES ......290 Arno Dal Ri Jr. e Andrey José Taffner Fraga

Control Judicial de la Corte Interamericana de Derechos Humanos y Programas Masivos de Reparaciones: Hacia un Enfoque más Matizado .309 Juan Carlos Ochoa-Sánchez 
JuSTICIABILIDADE DIRETA DOS DIREITOS ECONÔMICOS, SOCIAIS, CULTURAIS E AMBIENTAIS NA

Corte Interamericana DE Direitos Humanos..........................................................334

Augusto Antônio Fontanive Leal e Guilherme Massaú

How the indigenous case of Xukuru before the Inter-American Court of Human RiGHTS CAN INSPIRE DECOLONIAL COMPARATIVE STUDIES ON PROPERTY RIGHTS..........................353

Flavianne Fernanda Bitencourt Nóbrega e Camilla Montanha 


\title{
The immunity of international organizations in labour disputes. Developments before international tribunals, national courts and the colombian jurisdiction*
}

\author{
A imunidade das organizações \\ internacionais em controvérsias trabalhistas. \\ Desenvolvimentos perante tribunais \\ internacionais, cortes nacionais e na jurisdição \\ colombiana
}

\author{
Walter Arévalo-Ramirez ${ }^{* *}$ \\ Ricardo Abello-Galvis***
}

* Recebido em 20/10/2020

Aprovado em 13/07/2021

** Principal Professor of Public International Law at the Universidad del Rosario Law School in Bogotá, Colombia, and PhD Summa cum laude. Professor of International Law at the Diplomatic Academy of the Ministry of Foreign Affairs (Colombia). He has held posts as visiting researcher at The Hague University of Applied Sciences; the Arctic University of Norway (JCLOS Center for the Law of the Seas) and at the iCourts Center, University of Copenhagen, and as Tutor in The Hague Academy of International Law. Member of the editorial board of the ACDI - Colombian Yearbook of International Law, Secretary General of the Colombian Academy of International Law and Director of the Latin American Network of International Law Journals. Co-Director of the International Law postgraduate program at Universidad del Rosario (Colombia).

Email: walter.arevalo@urosario.edu.co

*** Principal Professor of Public International Law at the Universidad del Rosario Law School in Bogotá, Colombia. He is a member of the National Group of the Permanent Court of Arbitration and acted as agent for Colombia before the Inter-American Court of Human Rights (Advisory Opinion No. 23). Director and Editor of the ACDI - Colombian Yearbook of International Law. He holds visiting posts at the Nanterre University (France), Louvain-la-Neuve (Belgium), Westminster (London), American University (Washington), Alfonso X (Madrid), IEESFORD (El Salvador) and the Diplomatic Academy (Colombia). Director of the International Humanitarian Law and Human Rights postgraduate program at Universidad del Rosario (Colombia).

Email: ricardo.abello@urosario.edu.co

\begin{abstract}
The article aims to analyze and explain the recent developments and challenges regarding the jurisdictional immunity of international organizations in labour disputes, both by international and national courts, concluding with remarks on the experience of the Colombian case law in the matter. The article uses both case-law review and comparative law methodologies to first explain the main differences between diplomatic immunity and the immunity of international organizations regarding labour disputes, then, it describes the current legal trends regarding the applicable law to labour relations between international organizations and individuals, and the challenges to the immunity of the organization when disputes arise. The article develops the modern trend of requiring the organization to activate internal dispute resolution mechanisms to uphold its immunity before national courts. The article argues that there is an incomplete reception of the principles governing the immunity of international organizations by recent Colombian case law and that frequently, constitutional judges confuse the sources that regulate diplomatic immunity with the sources that regulate the immunity of international organizations. The article concludes that although international case law over the past decade widely recognizes functional immunity and jurisdictional immunity as the governing law in international organizations, it is still a controversial topic that has demanded fast developments regarding the applicable law, the differences with diplomatic immunity as understood by local authorities (expanding on the example of Colombia) and the design of innovative dispute resolution mechanisms within international organizations.
\end{abstract}

Keywords: Immunity of international organizations; Diplomatic immunity; Host State; national officials; functional immunity. labour disputes. 


\section{Resumo}

$\mathrm{O}$ artigo tem como objetivo analisar e explicar os desenvolvimentos e desafios recentes em relação à imunidade jurisdicional das organizações internacionais em conflitos trabalhistas, tanto por tribunais internacionais como nacionais, finalizando com observações sobre a experiência da jurisprudência colombiana no assunto. $\mathrm{O}$ artigo usa tanto a revisão da jurisprudência quanto as metodologias de direito comparado para primeiro explicar as principais diferenças entre a imunidade diplomática e a imunidade das organizações internacionais em relação a disputas trabalhistas; em seguida, descreve as tendências atuais em relação ao direito aplicável às relações de trabalho entre organizações internacionais e indivíduos e os desafios à imunidade da organização quando surgem controvérsias. $\mathrm{O}$ artigo explora a tendência moderna de exigir que a organização ative mecanismos internos de solução de controvérsias para manter sua imunidade perante os tribunais nacionais e, por fim, o artigo estuda a recepção incompleta dos princípios que regem a imunidade das organizações internacionais pela recente jurisprudência colombiana. $\mathrm{O}$ artigo conclui que, embora a imunidade funcional e a imunidade jurisdicional sejam amplamente reconhecidas como o direito que rege as organizações internacionais na jurisprudência internacional da última década, ainda é um tema polêmico que exigiu rápido desenvolvimento em relação ao direito aplicável aplicável, as diferenças com imunidade diplomática compreendida pelas autoridades locais (ampliando o exemplo da Colômbia) e o desenho de mecanismos inovadores de resolução de controvérsias nas organizações internacionais.

Palavras-chave: Imunidade de organizações internacionais; Imunidade diplomática; Estado anfitrião; Funcionários nacionais; Imunidade funcional; Disputas trabalhistas

\section{Introduction}

The present article seeks to explain the recent developments and challenges regarding the jurisdictional immunity of international organizations in labour disputes, both by international and national courts, concluding with remarks concerning the experience of Colombian case law in the matter.
The starting point for this analysis, is defining the scope of the conventional nature ${ }^{1}$ and scope of the immunity of international organizations and its differences with diplomatic immunity, along with the different nature of their exemptions and waivers. Furthermore, the article defends the non-applicability of the distinction between acts iure imperii and acts iure gestionis to international organizations as a defense to their immunity in labour disputes. The methodology uses comparative case law of both international and national tribunals and the article studies the principal differences between diplomatic immunity and functional immunity of international organizations in their labour relations with foreign and national citizens from the host State, arising from international practice.

To fully comprehend the current challenges ${ }^{2}$ that international organizations face with the courts of their host States and their employees, the article studies the legal nature of labour relations between international organizations and their staff, its applicable law, the dispute resolution mechanisms to which they are subjected and the grounds for upholding or waiving immunity in those situations, the article also analyzes modern examples of the Staff Regulations, the Constitutive Treaties and the available case law both from international courts and human rights court that have studied the issue, concluding with a review of the current standards in the matter.

Although the article reviews international case law from several courts and national case law from different States in the matter, the article extends its remarks on the Colombian case law regarding immunities of international organizations in labour disputes, a very particular case of judicial misapplication ${ }^{3}$ where national jud1 An historical approach to the nature of international organiza-
tions is necessary to complement the legal study of their conven-
tional, treaty-based nature, for a historical inquiry on international
organizations, See. MACKENZIE, David Clark. A world beyond bor-
ders: An introduction to the history of international organizations.
University of Toronto Press, 2010.
2 This article analyses the proposed issues from the perspective of
immunity as an institution of public international law. For a recent
study of the same topic as an issue of human rights, See. WEBB,
Philippa. The Immunity of States, Diplomats and International Or-
ganizations in Employment Disputes: The New Human Rights Di-
lemma?. European Journal of International Law, v. 27, n. 3, p. 745-767,
2016.
3 The present article analyzes immunities regarding labour disputes
in the Colombian case law and is a product of the research line on
international law and tribunals of the international research group
of the Law Faculty of Universidad del Rosario, Colombia. For a 
ges have confused the sources that regulate diplomatic immunity, with the conventional sources that in every singular organization, define the extent of the immunities of international organizations, and as a consequence, have applied the wrong exemptions to each type of immunity.

\section{The conventional nature and scope of the immunity of international organizations and its differences with diplomatic immunity, exemptions, and waivers.}

The immunity of international organizations is a legal prerequisite to freely and effectively exercise their object and purpose and their particular functions at the international level, both in the territory of the States Parties and especially in their relations with national authorities in the territory of the host State. The immunities granted to international organizations in their constitutive treaties and host State agreements exist to prevent local interference with their goals, which have been designed by the States Parties themselves, and seek to protect the international organizations from obstacles that may come from their day-to-day relations with legislative, judicial or executive powers of a State that voluntarily or circumstantially might want to truncate the goal-approached activity of the organization, thus affecting the fulfillment of its object and purpose and the activities of its organs and officials, and in consequence, violate their constitutive treaty. ${ }^{4}$

In the Latin American context, following the global trend to grant functional immunity to international organizations in their constitutive treaties ${ }^{5}$, the notion

previous article, part of the same research that analyzes the way in which Colombian judges have interpreted their jurisdiction regarding State immunities, immunities of international organizations and diplomatic immunities, in any types of disputes involving nationals, See. ABELLO-GALVIS, Ricardo, ARÉVALO RAMÍREZ, Walter. La inmunidad de las organizaciones internacionales y de sus funcionarios cuando son nacionales del Estado sede. Diferencias con la inmunidad diplomática y experiencias de la jurisprudencia internacional y colombiana. Anuario Mexicano de Derecho Internacional, v. XXI, 2021

4 EVANS, Malcolm. International Law. Fifth Edition. Oxford, 2018. 5 TESFAGABIR, Kibrom. The state of functional immunity of international organizations and their officials and why it should be streamlined. Chinese Journal of International Law, v. 10, n. 1, p. 97-128, that the immunity of international organizations and its scope is a matter of their constitutive treaty and is functional to their object and purpose, has been reflected in the regional framework of organizations such as the OAS, through organizational bodies tasked with documenting the international practice of the States of the region. Regarding the purpose and existence of functional jurisdictional immunity, the Inter-American Judicial Committee (Comité Jurídico Interamericano ${ }^{6}$ ) in its report on immunities of international organizations, has evidenced the regional trend as a guideline for States. As a legal foundation for functional immunity ${ }^{7}$, the Committee has considered immunity as a direct consequence of the creation of a new legal entity, which can be either an express or tacit creation in the constitutive treaty of the international organization. It has used the UN Charter and the OAS Charter as examples that show how the creation of a new legal entity in the head of the international organization, implies the concession of privileges, immunities and other attributes (special organs, budget) necessary to the fulfillment of their object and purpose.

Guideline 2.

Objective of jurisdictional immunity

Jurisdictional immunity is granted to international
organizations to make possible the realization of
their object and purpose.
Rapporteur's Notes (extracts)
In the inter-American sphere, the same tenor
is found in the Charter of the Organization of
American States, which Article 133 establishes that
the organization "... shall enjoy in the territory
of each one of its Members the legal capacity,
privileges and immunities that are necessary for
the exercise of its functions and the realization of
its purposes. "In the case of the Inter-American
Development Bank, its Constitutive Agreement
establishes that "for the fulfillment of its objective
and the performance of the functions conferred on
it, the Bank will enjoy, in the territory of each of
the member countries, the legal status, immunities,
exemptions, and privileges established in this
article. The Bank's Constitutive Agreement allows
the establishment of legal actions to the extent
that the Bank's purpose is to provide financing to

2011.

${ }^{6}$ LIMA, Lucas Carlos. "The OAS Inter-American Juridical Committee and the Codification of Regional International Law." Brazilian Journal of International Law, v. 16, p. 292, 2019.

WOOD, Michael. Do international organizations enjoy immunity under customary international law?. Immunity of International Organizations. Brill Nijhoff, 2015. p. 29-60. 
member states for development projects and, as part of its activity, must take action before national courts. Immunity is therefore strictly functional and allows, in this case, the initiation of procedures to achieve the object and purpose of the Bank. The Member States have granted jurisdictional immunity to international organizations to facilitate the achievement of their objectives with independence, economic rationality and without obstacles that, otherwise, they could face through the jurisdictional competence exercised by the courts of a Member State frustrating the will of most of the Member States.

The ultimate purpose of this immunity from jurisdiction is to ensure the independence of the organization and to avoid undue interference in the execution of its mandate. Otherwise, an organization would be subject to all kinds of legal actions that would make its work impossible. In the case Amaratunga v. Northwest Atlantic Fisheries Organization, the Supreme Court of Canada established that without immunity an international organization would be vulnerable to interference in its operations by the receiving State and by the courts of that State. ${ }^{8}$

This principle recognized by OAS as exemplified by the UN Charter and developed by the Latin American experience on international organizations, designates the immunity of international organizations as a special type of immunity that emanates from the constitutive treaty. It is closely related to the wording of its instruments, and is, hence, governed by the law of treaties, including the impossibility of limiting it unilaterally in any manner by interfering authorities in labour matters unless it is agreed in the treaty between the constituting States.

This has also been recognized in the comparative case law (as noted by OAS) in the Amaratunga v. Northwest Atlantic Fisheries Organization case of the Supreme Court of Canada. In the case involving NAFO, it was disputed whether national courts could consider that customary diplomatic international law, which usually limits diplomatic immunity in labour disputes, could be applied to international organizations, limiting the scope of immunity in the constitutive treaty and the host-State agreement (usually referred as Headquarters Agreement or Seat Agreement). The Supreme Court ${ }^{9}$ held that the

\footnotetext{
8 (Section Translated from Spanish by the authors). OAS. Informe del comité jurídico interamericano. Inmunidades de las organizaciones internacionales, (93o período ordinario de sesiones OEA/ Ser. Q 6 al 16 de agosto 2018) CJI/doc.554/18 rev.2 Rio de Janeiro, Brasil. 16 agosto 2018.

9 VAN ERT, Gib; ALLEN, Greg J.; ROBB, Rebecca. Canadian
}

immunity of international organizations is strictly governed by treaty law and national courts cannot modify the agreement on immunity, even if they face situations in which employees face major constraints in the exercise of their right to legal procedure (see the relevant operative clause of this judgment in the footnote). ${ }^{10}$

Cases such as Amaratunga in which the immunity of international organizations is unilaterally challenged by the States seeking to establish restrictions within their reach, especially in labour matters, or in relation to certain types of officials, (e.g. exempting immunity when disputes arise between the organization and employees that are nationals to the host State), are the fundamental reason for defending at the jurisprudential level the profound differences between the immunity of international organizations and the immunity of diplomatic missions and personnel, which are, on the contrary ${ }^{11}$ governed by customary international law.

In the matter of diplomatic relations, immunity does not emanate from what is agreed in a specific instrument as occurs with each of the international organizations in its own constitutive agreement and the specific headquarters agreement when it further specifies privileges and immunities with the host State.

On the contrary, the foundation for diplomatic immunity is the sovereignty of the State in its international relations, and the application of Westphalian principles, such as the principle of equality between States and the impossibility of acts of empire between peers,

Cases in Public International Law in 2013. Canadian Yearbook of International Law, v. 51, p. 535, 2013.

10 Amaratunga $v$. Northwest Atlantic Fisheries Organization, 2013 SCC 66, [2013] 3 S.C.R. 866 https://scc-csc.lexum.com/scc-csc/ scc-csc/en/item/13364/index.do: Extract: "Without immunity, an international organization would be vulnerable to intrusions into its operations by the host state and that state's courts. However, no rule of customary international law confers immunity on international organizations. Instead, they derive their immunity from treaties, or in the case of smaller international organizations like NAFO, from agreements with host states. [...] To allow employment related claims of senior officials to proceed in Canadian courts would constitute undue interference with NAFO's autonomy in performing its functions and would amount to submitting its managerial operations to the oversight of its host state's institutions. The absence of a dispute resolution mechanism or of an internal review process is not, in and of itself, determinative of whether NAFO is entitled to immunity. While the fact that $A$ bas no forum in which to air his grievances and seek a remedy is unfortunate, it is the nature of an immunity to shield certain matters from the jurisdiction of the host State"

11 BARKER, J. Craig; WARBRICK, Colin; MCGOLDRICK, Dominic. State Immunity, Diplomatic Immunity and Act of State: A Triple Protection against Legal Action?. The International and Comparative Law Quarterly, v. 47, n. 4, p. 950-958, 1998. 
"Non enim una civitas potest facere legem super alteram, quia par in parem non habet imperium". These State-to State legal principles, all informing international customary law ${ }^{12}$ as codified by the Vienna Convention on Diplomatic Relations ${ }^{13}$, have historically and universally included restrictions, exceptions, and all sorts of limitations regulated by custom (the VCDR being one of the cases in which a multilateral treaty reflects and reinforces customary international law, under the well-known Baxter ${ }^{14}$ Paradox ${ }^{15}$ ). They are applied to all diplomatic missions when it comes to private commercial acts and labour disputes between the diplomatic missions, diplomatic agents and employees from the receiving State. This is a very different matter from the world of international organizations where the immunity of every single organization must be subject of an ad hoc analysis of their conventional instruments and the way that immunity has been negotiated in each treaty.

These types of general exemptions to immunity in labour disputes and labour relations with employees from the receiving State, common in diplomatic relations, cannot be extended to the interpretation of the immunity of particular international organizations. They do reflect diplomatic customary international law but are not to be implied in the law of international organizations, and are codified in the Vienna Convention on Diplomatic Relations (VCDR), which justifies limiting their scope only to diplomatic immunity, as seen in articles such as Art. 33 , numerals 1 to 3 , governing social security provisions of diplomats in the receiving State:

Article 33

1.Subject to the provisions of paragraph 3 of this article, a diplomatic agent shall with respect to services rendered for the sending State be exempt

\footnotetext{
12 ABELLO-GALVIS, Ricardo. La Costumbre como Fuente de Derecho Internacional: una Caja de Pandora Imposible de Cerrar. Derecho internacional: varias visiones, un maestro. Liber amicorum en homenaje a Marco Gerardo Monroy Cabra. 2015: 3-28. Ed. Universidad del Rosario.

13 DENZA, Eileen. Diplomatic law: commentary on the Vienna convention on diplomatic relations. Oxford University Press, 2016.

14 SARMIENTO LAMUS, Andrés. ¿Es la "Paradoja Baxter" una verdadera paradoja? La práctica de los Estados, entre la formación del derecho internacional consuetudinario y la interpretación de tratados". In: ABELLO-GALVIS, Ricardo; ARÉVALO RAMÍREZ, Walter. (ed.) Derecho Internacional Público, Derecho Internacional de la Inversión Extranjera. Universidad del Rosario. 2019. p. 57 - 75.

15 BAXTER, Richard R. Multilateral Treaties as Evidence of Customary International Law. British Yearbook of International Law, v. 41, p. $275,1965$.
}

from social security provisions which may be in force in the receiving State.

2.The exemption provided for in paragraph 1 of this article shall also apply to private servants who are in the sole employ of a diplomatic agent, on condition:

(a) That they are not nationals of or permanently resident in the receiving State; and

(b) That they are covered by the social security provisions which may be in force in the sending State or a third State.

3.A diplomatic agent who employs persons to whom the exemption provided for in paragraph 2 of this article does not apply shall observe the obligations which the social security provisions of the receiving State impose upon employers. [... $]^{16}$

Also, limitations to immunities based on the nationality of the employee or member of the Mission are common ground in the customary law of diplomatic relations (i.e. Art. 38 of the Vienna Convention on Diplomatic Relations). This is not true, however, in the law of international organizations, where an organization can grant different degrees of immunity to national or foreign employees based only upon the agreement with the host State. This can range from full jurisdictional immunity to national and foreign officials, to limiting, via treaty clauses in the constitutive agreement and the headquarters agreement, the immunity of national staff. This is an analysis that cannot be generalized and only depends upon the particular treaties of each organization.

Article 38.1: Except insofar as additional privileges and immunities may be granted by the receiving State, a diplomatic agent who is a national of or permanently resident in that State shall enjoy only immunity from jurisdiction, and inviolability, in respect of official acts performed in the exercise of his functions. 2.Other members of the staff of the mission and private servants who are nationals of or permanently resident in the receiving State shall enjoy privileges and immunities only to the extent admitted by the receiving State. However, the receiving State must exercise its jurisdiction over those persons in such a manner as not to interfere unduly with the performance of the functions of the mission.

Therefore, it is essential to understand the differences between the two types of immunity and their origins in order to understand the true scope of immunity of international organizations, especially when it comes to issues that national courts unduly believe are "naturally"

\footnotetext{
16 Vienna Convention on Diplomatic Relations https://legal.
} un.org/ilc/texts/instruments/english/conventions/9_1_1961.pdf 
exempt from immunity, such as labour disputes or disputes involving officials who are nationals of the host State in which the organization is based.

The immunity of international organizations is, when compared to immunity of States ${ }^{17}$ and diplomatic envoys, a very recent and practical development of modern international law in the twentieth century where the dominant instrument are treaties and the functional approach to international organizations allows a very institutional and text-based approach to immunities and privileges.

On the other hand, the immunity of States and diplomatic missions feeds on the classic concept of sovereignty and is embodied in international customs aimed at protecting heads of State, progressively extending throughout history to their envoys abroad. It has historically admitting a large number of exceptions, creating a diplomatic regime which at the time of being conceived did not contemplate or pretend to regulate, either the future concept of an international official of an organization or the modern possibility that an international organization, within its own legal capacity would employ nationals of its host State as officials, and whether such officials, in order to be able to carry out their functions, would be granted immunity, and the extent thereof, within their own nation States of said immunity was never contemplated by the early grounds of diplomatic immunity. ${ }^{18}$

For Flaherty, diplomatic immunity protects State equality and the sovereignty involved in certain acts of State. On the contrary, functional immunity of international organizations, aims to protect the impartiality, independence and the limited resources involved in every act related to the fulfillment of the object and purpose of the organization: "The immunity granted to international organizations (IOs.) comes from the foreign sovereign immunities tradition mentioned above. However, it is justified by a theory of "functional necessity," which came into being after World War II, when emerging 1 Os needed support from the States in order to achieve a certain degree of maturity and therefore to be able to perform their duties in an unfettered manner. This kind of im-

\footnotetext{
${ }^{17}$ QUINTANA ARANGUREN, Juan José; GUZMÁN CARRAS CO, Gonzalo. De espaldas al derecho internacional: Colombia y la inmunidad de jurisdicción de los Estados. International Law: Revista Colombiana de Derecho Internacional, v. 8, p. 53-102, 2006.

${ }_{18}$ MULLER, A. Sam. International organizations and their host states: aspects of their legal relationship. Martinus Nijhoff Publishers, 1995. v. 21
}

munity was based on the idea that it would serve the best interests of the organizations by keeping them protected from potential lawsuits that would negatively affect the organizations' limited resources at that time or their ability to operate independently. For IOs, immunity was supposed to ensure theirpolitical and financial independence and therefore their impartiality. Since immunity of IOs came into being before the restrictive immunity theory had been adopted by many sovereign states, it was conceived and codified as being absolute. Many of these organizations actually have it codified in their own constituent instruments and other international treaties. It can also exist in the form of headquarters agreements, regional agreements, and conference agreements. These treaties, due to their international law character, are to be considered internal law of the signatory States (at least for those in which treaty law is self-executing." 19

Starting from this idea of the immunity of international organizations as an immunity that is analyzed case by case according to how it had been agreed upon in the constitutional instrument of the organization by the States Parties, it is usual to find that absolute immunity is established in general terms both for administrative and judicial actions. The intent is to grant the organization jurisdictional immunity with respect to all proceedings regardless of the nature of the process, either commercial, criminal, civil, extra-contractual, labour or of any another legal nature. This jurisdictional immunity has been interpreted as including the right to not appear before national courts when summoned by them, and also indicating that the act of appearance by an international organization, before a national court, to assert its own immunity before a judicial, administrative or diplomatic authority, never implies by itself a waiver of it, as has been recognized by the OAS Inter-American Judicial Committee:

\section{Guideline 8.}

\section{Appearance before national courts}

Without prejudice to their immunity from
jurisdiction, international organizations should
appear before national courts to assert their
immunity or file exceptions.
Rapporteur's Notes
[...] There is no consistent practice among
international organizations and Member States
regarding the appearance before national courts at
the time of being notified about the establishment
Im., FLAHERTY Edward. International Organiza-
Comparative Law, v. 16, p. 433, 2009.

19 RIOS, Greta L., FLAHERTY Edward. International Organization Reform of Impunity-Immunity is the Problem. ILSA Journal of International \& Comparative Law, v. 16, p. 433, 2009. 
of a process. Particularly when it comes to cases covered by jurisdictional immunity, the international organization will not want to compromise it by appearing in court or even invoking its immunity.

To remedy this situation, the international organization should appear through diplomatic channels to that through the Ministry of Foreign Relations immunity is asserted or exceptions are presented. However, there may be cases where the Ministry of Foreign Affairs or any other state authority are entitled to appear before national courts. In congruence with the general obligation to cooperate with national authorities, as developed in Guideline 7 above, a good practice would consist in the appearance of the international organization in the interest of the own organization. On the one hand, it would allow the organization to assert its immunity and, on the other hand, it would be the procedural space to enforce exceptions. ${ }^{20}$

The OAS Guideline is consistent with the scope given to the usual general expressions "any administrative actions" or "any judicial actions" when talking about jurisdictional immunity, found in constitutive treaties, by the most recognized doctrine ${ }^{21}$ and the case law, which usually find constitutive treaties broadly mentioning the term "judicial actions" when establishing the immunities of an organization, without specifying whether they are criminal, civil, labour or of another nature:

As international organizations are creations
of treaty, the determination of the scope of
their immunity is usually a task that entails the
interpretation and application of the relevant treaty
provision. "A treaty shall be interpreted in good
faith in accordance with the ordinary meaning to
be given to the terms of the treaty in their context
and in the light of its object and purpose." 50 With
respect to the United Nations, "Any interpretation
of the provisions of the General Convention must
be carried out within the spirit of the underlying
principles of the United Nations Charter, and in
particular Article 105 thereof, which provides that
the Organization shall enjoy such privileges and
immunities as are necessary for the fulfilment of its
purposes. Moreover, in accordance with article 26
of the Vienna Convention on the Law of Treaties,
1969 ... every treaty in force is binding upon the
parties to it and must be performed by them in good
faith." 51 Immunity of international organizations
from "every form of legal process" has been broadly
interpreted to include all legal proceedings before

${ }^{20}$ (Section Translated from Spanish by the authors). OAS Informe del comité jurídico interamericano. Inmunidades de las organizaciones internacionales, (93o período ordinario de sesiones OEA/ Ser. Q 6 al 16 de agosto 2018) CJI/doc.554/18 rev.2 Rio de Janeiro, Brasil. 16 agosto 2018.

${ }^{21}$ OKEKE, Edward Chukwuemeke. Jurisdictional immunities of states and international organizations. Oxford University Press, 2018. p. 294. national (administrative, judicial, or executive) authorities. It applies regardless of whether the international organization is a defendant or witness. The immunity does not preclude the organization, in its own determination, from participating in such proceedings. However, the initiation of court proceedings by an international organization may be construed as a waiver of its jurisdictional immunity in that particular case

This formula adopted by several constitutive conventions of international organizations, tending to specify that the immunity will be "from all types of jurisdiction" (criminal, administrative, labour, etc.), has been accompanied by the specification that any waiver to jurisdiction must be an express act of the organization or an express treaty provision. Additionally, a waiver of immunity from jurisdiction would not imply admitting enforceable measures, meaning that waiving immunity from jurisdiction does not create any waiver for enforcement, as is clearly exemplified in the Convention on the Privileges and Immunities of the Specialized Agencies (United Nations) in its Art. 3, Sec. 4, which has been used as template for multiple constitutive and headquarters agreements.

Article III PROPERTY, FUNDS AND ASSETS Section 4 . The specialized agencies, their property and assets, wherever located and by whomsoever held, shall enjoy immunity from every form of legal process except in so far as in any particular case they have expressly waived their immunity. It is, however, understood that no waiver of immunity shall extend to any measure of execution.

\section{The non-applicability of the distinction between acts iure imperii and acts iure gestionis to international organizations as a defense to their immunity in labour disputes.}

Academic literature has reiterated the impossibility of exempting or revocating the immunity of international organizations in labour disputes unilaterally or by invoking general customary exemptions, as often occurs with diplomatic missions due to their different nature. This is consistent with the conclusion by specialized literature that States, when recognizing the international subjectivity of an international organization, cannot 
equate the nature and scope $\mathrm{e}^{22}$ of its immunity with that of the immunity of diplomatic missions or with State ${ }^{23}$ immunity, taking into account that the differences between acts "iure imperii" and acts "iure gestionis", usually considered when studying the nature of the behaviour of a diplomatic envoy, are not applicable to the functioning of an international organization:

This immunity from jurisdiction prevents law suits against organizations before domestic courts unless they have waived their immunity by consenting to the proceedings. As has been the case with State immunity, there has been pressure to restrict the absolute nature of the immunity granted to international organizations. Indeed, a number of domestic courts have applied to international organizations the concept of restrictive immunity, granting them jurisdictional immunity only in relation to acts jure imperii (in the exercise of sovereign authority) rather than acts jure gestionis (done privately). Alternatively, it has been argued that the grant of immunity should be conditional on the presence of alternative methods of resolving disputes involving international organizations (Gaillard and Pingel-Lenuzza, 2002). The first approach, which relies on an analogy with State immunity is based on the misapprehension that since international organizations are composed of States they are to be placed in the same position as foreign States. This approach is incorrect for at least two reasons. First, it is contrary to the express provisions of the relevant treaties. Secondly, international organizations are not sovereign entities and do not exercise sovereign authority. Their immunity is not granted to protect sovereign or public acts but is functional and granted in respect of acts done in the exercise of their functions. Such functions and acts may well be commercial and so classified as private if done by a State. Thus immunity may arise for an international organization in cases where a foreign State will be denied immunity. For example, employment disputes fall within the immunity of an international organization even if the relations with the particular employee might be classified as jure gestionis. The second approach, which conditions immunity on the existence of alternative dispute resolution mechanisms, seeks to give effect to the right of access to a court provided in human rights treaties and is reflected in the case law of the European Court of Human Rights. ${ }^{24}$

\footnotetext{
22 STEWART, David P. The UN Convention on Jurisdictional Immunities of States and Their Property. The American Journal of International Law, v. 99, n. 1, p. 194-211, 2005.

23 WOJCIKIEWICZ ALMEIDA, Paula. L'affaire des immunités juridictionnelles de l'Etat (Allemagne c. Italie): la Cour Internationale de Justice à contre-sens de l'évolution du droit international. $A C$ DI-Anuario Colombiano de Derecho Internacional, v. 11, p. 21-70, 2018.

${ }^{24}$ EVANS, Malcolm. International Law. Second Edition. Oxford, 2006. p. 408-411.
}

The OAS guidelines also reject the applicability of the distinction, based upon customary international law, of acts iure imperii and acts iure gestionis to international organizations. They categorically state that the scope of functional immunity covers all types of acts of the organizations performed to fulfill its object and purpose.

This is regardless of whether they resemble political acts, decisions of the governing bodies of the organization or constitute acts performed via private contracts or commercial relations, and make clear that limitations can only arise from express agreement between the member States or the organization and the host State in its headquarters agreement, and cannot be unilaterally established by national courts:

\section{Guideline 3.}

Scope of jurisdictional immunity

International organizations, their property and assets enjoy immunity against all judicial proceedings regarding acts carried out to achieve their object and purpose, except in cases where the organization expressly waives this immunity.

Rapporteur's Notes

$[\ldots]$

As regards international organizations, immunity tends to be functional based on the presumption that it is only appropriate to recognize this immunity for the activities of the organizations that are essential and necessary to achieve their object and purpose. The treaties of each organization establish the acts inherent to the purpose of the organization and, therefore, covered by immunity. However, Member States establish the scope of jurisdictional immunity to be recognized by their national courts. At the same time, the host State agrees with the organization the type of jurisdictional immunity it will enjoy in its territory.

Jurisdictional immunity is granted to the international organization as such and covers the acts it performs in pursuit of its object and purpose. By virtue of this, the organization's assets are also protected. Although the scope of this Guide is limited to jurisdictional immunity, it should be specified that jurisdictional immunity covers property and assets, in order to safeguard them against any claim faced by the international organization.

The fact that the customary limits to diplomatic immunity are not applicable to the immunity of international organizations, does not opposes, quite the contrary, that fact the principles governing functional immunity are at the same time enjoying strong reception by national courts that in some cases have considered the notion 
of "functional immunity" as an emerging principle of customary law governing international organizations ${ }^{25}$.

National courts have repeatedly given recognition to the existence and necessity of functional immunity for international organizations within their territory and have customarily recognized immunity from jurisdiction as a principle ${ }^{26}$ that does not violate national sovereignty, but this does not mean that the exceptions and limitations to such immunity exist outside of those expressly agreed in the constitutive agreement or in the headquarters agreement of each organization and that they can be applied universally by national courts, as is the case with diplomatic immunity where its customary limits are widely accepted and practiced ${ }^{27}$.

This reception of the immunity of international organizations by national $\operatorname{courts}^{28}$ has even come to be recognized as a principle of international law in judicial decisions ${ }^{29}$ which have indicated that national courts cannot restrictively interpret the immunity of international organizations by assimilating it to diplomatic immunity, thus constituting an Ultra vires ${ }^{30}$ decision.

This was recognized in a seminal ruling by the Belgian Courts of Appeals in the Manderlier ${ }^{31}$ case. This judgment recognized that the Belgian lower courts shall not restrictively interpret the United Nations Convention on Privileges and Immunities ${ }^{32}$, not even under the idea of allowing the right to access to justice for a plaintiff against the organization, since the claim befo-

${ }_{25}$ WOOD, Michael. International Organizations and Customary International Law. Vanderbilt journal of transnational law, v. 48, n. 3, p. 609,2015

${ }_{26}$ GODIO, Leopoldo. Evolución, actualidad y tendencias en materia de privilegios e inmunidades de organismos internacionales. Revista RECORDIP, v. 1, n. 2, 2011.

${ }^{27}$ BROWN, Jonathan. Diplomatic immunity: State practice under the Vienna convention on diplomatic relations. International and Comparative Law Quarterly, v. 37, p. 53, 1988

${ }_{28}$ REINISCH, August. International organizations before national courts. No. 10. Cambridge University Press, 2000.

29 Including: X et al. v.European School Munich I63 the Bavarian appellate Administrative Court, US-Iran Claims Tribunal v AS, 96 ILR 321, 329 (Netherlands Supreme Court, 1985)

${ }^{30}$ BELGIUM. Brussels Appeals Court. Manderlier v. United Nations and Belgian State: Decision of 15 September 1969

31 Brussels Appeals Court. Manderlier v. United Nations and Belgian State: Decision of 15 September 1969.United Nations Juridical Yeabook 1969. https://legal.un.org/unjuridicalyearbook/pdfs/ english/by_volume/1969/chpVIII.pdf

32 MILLER, Anthony. Privileges and immunities of United Nations officials. International Organizations Law Review, v.4, n. 2, p. 169-257, 2008. re the national courts was an obvious limitation to his immunity;

With regard to the argument that Article 105 of the United Nations Charter limited the privilege of immunity to the minimum necessary to enable the United Nations to fulfil its purposes, the Court replied that in acceding to the Convention of 13 February 1946, the signatories of the Charter had defined the necessary privileges and immunities and that the courts would be exceeding their authority if they were to arrogate to themselves the right of determining whether the immunities granted to the United Nations by that Convention were or were not necessary. ${ }^{33}$

\section{Principal differences between diplomatic immunity and functional immunity of international organizations in their labour relations with foreign and national citizens from the host State, arising from international practice.}

The differences between these types of immunities, diplomatic and functional, usually arise from obvious situations in the daily practice of international relations, which must later be elaborated in the legal field. One of those obvious realities is that international organizations do not have their own territory in which to install their organs, bodies, buildings and agents and freely exercise their powers. They are always within the territory of a State Party that has decided to be its host State. This necessarily means that they are always at the mercy of some possibility of vulnerability and interference by administrative or jurisdictional authorities of that State.

Unlike States, international organizations do not have a permanent population, so it is natural that they make up their staff of officials with nationals of the States parties and specifically those that they find among the nationals who live in the host State, constituting a potential labour force for the organization.

Also, unlike diplomatic missions, the immunity of officials of international organizations does not ema-

\footnotetext{
33 Brussels Appeals Court. Manderlier v. United Nations and Belgian State: Decision of 15 September 1969. United Nations Juridical Yeabook 1969. https://legal.un.org/unjuridicalyearbook/pdfs/ english/by_volume/1969/chpVIII.pdf
} 
nate from or is exempted according to their bond of nationality, as occurs with members of the diplomatic mission accredited abroad and with other institutions of international law based on nationality, such as diplomatic protection ${ }^{34}$.

On similar grounds, the International Court of Justice has repeatedly recognized that the limitations to the immunity of international organizations and their agents can only be express and it is not possible to limit jurisdictional immunity unilaterally by the host State, a position which was settled in the advisory opinion "Mazilu" 35 and in the advisory opinion "Immunity from legal process of a Special rapporteur" ${ }^{36}$.

The differences between diplomatic immunity and immunity of international organizations can also be observed in the mechanisms available for judging the responsibility of officials protected by immunity with respect to their acts and the possibility that they have a natural judge as a consequence of that immunity.

In the field of diplomatic immunity, the diplomatic envoy and member of a diplomatic mission abroad may have immunity from the courts of the receiving State but will always be subject to the disciplinary and criminal jurisdiction of its State of origin. This situation is also customary in nature and has been codified by the Vienna Convention on Diplomatic and Consular Relations.

Article 31.4:The immunity of a diplomatic agent from the jurisdiction of the receiving State does not exempt him from the jurisdiction of the sending State.

This inter-state logic in matters of immunity cannot be used to suppose that the official of an international organization does not have immunity when he or she is a national of the State where it is hosted, since his or her function is not that of a representative of a State and a subject of that State jurisdiction: His or her immunity emanates from what was agreed for the organization with its States parties and the host State.

\footnotetext{
${ }^{34}$ MACLEAN, Robert Joseph-Blaise; ARÉVALO RAMÍREZ, Walter. The Expulsion of Resident Colombian Nationals during the Colombia-Venezuela Border Dispute: An "Under the Radar" Case for Diplomatic Protection of Human Rights?. Vniversitas, v. 68, p. 138, 2019.

35 Applicability of Article VI, Section 22, of the Convention on the Privileges and Immunities of the United Nations, Advisory Opinion, I.C.J. Reports 1989, p. 177.

${ }^{36}$ Diference Relating to Immunity from Legal Process of a Special Rapporteur of the Commission on Human Rights, Advisory Opinion, I.C.J. Reports 1999, p. 62
}

The same argument operates in labour disputes. If the State and the Organization exempted, waived or restricted labour disputes that might arise with employees that are nationals of the host State and the organization, and this was waived in the constitutive treaty or in the headquarters agreements, there will be no immunity. On the contrary, if full immunity from jurisdiction was granted to the organization, making no exemption or waiver, the immunity will cover any labour dispute.

The acts of officials of international organizations and their natural judge are not classified "by default" with respect to a State of origin, or the receiving or sending State as one would consider in diplomatic immunity. For international organizations and their officials, whether or not they are nationals of the host State, the natural judge, as practice has shown (And has been recounted by several international bodies ${ }^{37}$, such as the Parliamentary Assembly of the Council of Europe, which in 2014 commissioned an ongoing study on immunities of international organizations and their labour dispute resolution mechanism), is the international organization itself through its institutional mechanisms for internal dispute resolution and the rules devised in their treaty. These organizational dispute resolution mechanisms (also referred as administrative tribunals) are competent for multiple topics, including, the discipline of their officials, labour disputes or private contracts with local commercial entities, and have even recently been recognized as a necessary mechanism to deal with the immunities agreed in the treaties for the organization and its officials, in order to guarantee the applicants' human right to defense and access to justice. This issue may arise when, paradoxically, the same officials who wish to take action against the organization, for example in a labour matter, cannot do so because the organizations has immunity from local courts and procedures. This is an issue that will be studied in detail ahead in the present article.

The inherent powers of international organizations to establish these type of tribunals or dispute resolution mechanisms in the context of their immunity and as an expression of their functional capacity to fulfill their object and purpose were recognized in the advisory opi-

\footnotetext{
37 Resolution 1979 (2014)1 Accountability of international organizations for human rights violations Parliamentary Assembly. Council of Europe. https://assembly.coe.int/nw/xml/XRef/Xref-DocDetails-en. asp?FileID $=20510$ \&lang $=\mathrm{en}$
} 
nion "Effect of Awards of Compensation Made by the UN Administrative Tribunal":

\begin{abstract}
It was inevitable that there would be disputes between the Organization and staff members as to their rights and duties. The Charter contains no provision which authorizes any of the principal organs of the United Nations to adjudicate upon these disputes, and Article 105 secures for the United Nations jurisdictional immunities in national courts. It would, in the opinion of the Court, hardly be consistent with the expressed aim of the Charter to promote freedom and justice for individuals and with the constant preoccupation of the United Nations Organization to promote this aim that it should afford no judicial or arbitral remedy to its own staff for the settlement of any disputes which may arise between it and them. ${ }^{38}$
\end{abstract}

These internal courts of international organizations are precisely part of the institutional machinery of functional immunity which ensure that the lack of local jurisdiction for the States is not considered by national courts as a violation of their sovereignty, or of the right to access to justice ${ }^{39}$ of plaintiffs for certain types of applications against the organization. They present compelling reasons for the States not to try to dilute or deny the immunity of the organization.

Recent cases both in comparative law and before regional human rights courts, as will be analyzed below, have established that these internal mechanisms or courts, as a component of the recognition of the organization's immunity, in their procedure for labour disputes involving officials and the international organization, as an offset for the immunity, must comply with basic principles of law, such as those of impartiality, motivation of the decision, independence of the members of the panel among others. For example, this was debated in the Siedler ${ }^{40}$ case argued from 2003 to 2009 in the Belgian courts.

$$
\begin{aligned}
& \text { 47. The grant of privileges and immunities to } \\
& \text { international organizations is necessary to permit } \\
& \text { the good functioning of these organizations } \\
& \text { without any unilateral interference by a national } \\
& \text { government. The fact that states generally grant } \\
& \text { immunity from jurisdiction to international }
\end{aligned}
$$

\footnotetext{
38 Effect of Awards of Compensation Made by the U.N. Administrative Tribunal, Advisory Opinion, 1954 I.C.J. 47 (July 13)

39 ARAÚJO KALLÁS, Fernanda. A imunidade de jurisdição das Organizações Internacionais face ao direito de acesso à justiça. Revista de Direito Internacional - Brazilian Journal of International Law, v. 13, n. 3, 2016.

40 Siedler v. Western European Union, Belgian Labor Court of Appeals, Brussels, September 17, 2003, Journal des Tribunaux 2004, 617.
}

organizations in their constitutive instruments or in additional agreements constitutes a long-dated practice, aimed to ensure the good functioning of international organizations. The importance of this practice is reinforced by the tendency to enlarge and intensify international cooperation, which is illustrated in all domains of contemporary society. In these conditions, the rule of immunity from jurisdiction of international organizations pursues a legitimate aim

48. The question of whether the immunity was proportionate to the aim pursued should be evaluated in light of the particular circumstances of each case. To determine whether the restriction of fundamental rights flowing from such immunity was compatible with art. 6(1) of the ECHR, it was important to examine, in accordance with the jurisprudence of the ECtHR, whether the individual against whom such immunity was invoked had access to other reasonably available means to protect his or her rights. Article 6(1) of the ECHR did not prevail over the WEU's immunity (paras. 48-9).

$[\ldots]$

53. When determining whether the immunity invoked by the international organization could be reconciled with art. 6(1) of the ECHR, the court was not to limit itself to merely taking note of the characterization of an internal appeals commission as independent by the instrument which established that commission. The mode of designation-by an intergovernmental committee-and the short term of the mandate-two years — of the members of the commission were to be taken into account as well. These features of the internal appeals commission involved the risk that the members would be closely tied to the organization, thereby lacking independence. ${ }^{41}$

According to the Belgian Courts, as long as there is another reasonably available mean for the plaintiff to protect his or her rights before the organization, such as an internal labour dispute mechanism, the immunity of international organizations to labour disputes granted in its constitutive treaty does not violates the ECHR.

\section{The legal nature of the labour relations between international organizations and their staff: Applicable law, dispute resolution and grounds for immunity.}

Under the immunity of international organizations and their capacities in the exercise of their legal personality ${ }^{42}$, the contractual relations between them and 
private subjects, for example, the provision of services, goods, and regarding employment contracts, are not governed by any regime of national law. Rather, they are governed by the contractual autonomy of the organization and its will in choosing the applicable law. This is a consequence of the principle "lex contractus". The applicable law to these relations can be stipulated in the particular contract between the organization and the individual, or can be chosen beforehand in the organizational law of the international organization, contained in its constitutive treaty, the headquarters agreement or in particular resolutions produced by the binding organs of the organization regarding the employment procedure.

Relevant case law and doctrine on the matter recognize that it is usual for international organizations, when it comes to employment contracts or services, involving local officials, to "choose" the national law from the place where they provide their services as the law applicable to the contractual relationship. This, however, is only as a matter of convenience and not as an exemption to jurisdictional immunity. It is also usual, in the case of international staff members, to apply a particular labour law regime developed within the international organization in its resolutions. This applicable law is different from the national labour law of the host State ${ }^{43}$, is usually developed in the "Staff Regulations" of the organization and is subject to its own dispute resolution mechanisms.

The choice of the applicable law by the international organization in its services or employment contracts, whether it be to decide to enter into the contract applying the national labour law or under the application of the organization's own special labour law regime, does not imply a waiver of the jurisdictional immunity before the host State and its national courts. This, as explained earlier, is because that renunciation to the immunity as stipulated in the constitutive treaty can only emanate from a specific act by the organization, a stipulation in the treaty itself, or a clause in the headquarters agreement.

Manual de derecho internacional público. Fundamentos, tribunales internacionales y casos de estudio. 2da Ed. España: Tirant Lo Blanch Editorial, 2020.

${ }^{43}$ RYNGAERT, Cedric. Immunities of International Organizations Before Domestic Courts: Reflections on the Collective Labour Case Against the European Patent Organization. Netherlands Yearbook of International Law, 2015. TMC Asser Press, The Hague, 2016. p. 393-408.
11. In addition to national law, international law may be applicable to contracts between international organizations and private parties. Clearly, international law may become relevant as the law expressly chosen by the parties. This is the practice in the case of some international financial institutions which, in their loan agreements, expressly exclude national law and provide for the application of international law and/or general principles of law (see also $\rightarrow$ Debts). Though this practice is mainly pursued in loan agreements with States, it is also sometimes used in contracts with private parties. Other international development banks generally subject their lending and borrowing activities to national law. Since international law may not be as detailed and refined as national contract law, its usefulness as lex contractus may be limited. ${ }^{44}$

This phenomenon, characterized as "denationalization" or "internationalization" of the contractual relations of the organization and private subjects, has been promoted as a way to guarantee neutrality both from the jurisdiction of the State and its power to easily modify national labour law, but also has been performed partially, since it is recognized that the local labour force of the organization, charged with daily tasks, is usually hired under the national law of the host State, while the international staff, is usually hired under the organization's own labour law regime.

Also, an 'internationalization' of contracts
between international organizations and private
parties may be less important than in the case of
$\rightarrow$ contracts between States and foreign private
law persons. There such a 'denationalization' of
contracts serves the purpose of insulating them
from the power of States to change their own law
and thus to abrogate the contractual obligations
they have entered into with private parties. Since
international organizations do not have their own
legal order comparable to a State's 'national' law
they cannot manipulate it to their advantage. Thus,
any national law chosen may be regarded as neutral.
12 The closest equivalent to a State's national law, the
internal law of an international organization, is of
relevance in the special case of certain employment
contracts with organizations. However, as a rule,
not all kinds of employment relationships with,
or quasi-permanent provisions of services to,
international organizations are governed by such
internal law. Rather, there is a general distinction
between permanent staff and local or technical
staff as well as less regular service providers. The
precise delimitation between these two categories
of persons providing services to international
International Law, v. 7, p. 754-7, 2006.
zations and Private Law Persons. Max Planck Encyclopedia of Public International Law, v. 7, p. 754-7, 2006. 
organizations is difficult in practice. The latter types of contractual relations are usually governed by national law, either contractually chosen or determined by the applicable conflict of laws rules.

13 Employment contracts between international organizations and their staff members, on the other hand, are regularly exempted from national law. Instead, they are governed by internal employment law, sometimes also referred to as internal administrative law. It is usually codified in internal secondary law, often called Staff Rules and Regulations, and frequently supplemented by general principles of law, in particular of employment law. This exemption from national employment law, together with the immunity from national labour courts, is often regarded as necessary in order to create and maintain a uniform and independent international civil service which usually enjoy exclusive jurisdiction over staff disputes, frequently assert that they are 'bound exclusively by the internal law of the Organization ... as well as by general principles of law' (Re Waghorn ILO Administrative Tribunal Judgment No 28 [12 July 1957]). National employment law may become relevant, however, when there is an express choice of law or reference to it in the contract or staff rules or when it might be viewed as reflecting a general principle of employment law (Re Kock, N'Diaye and Silberreiss ILO Administrative Tribunal Judgment No 1450 [6 July 1995]). ${ }^{45}$

Under this strict application of functional immunity to jurisdiction and immunity from enforcing measures, it is not uncommon to find, inside the "staff regulations" of the international organization, or in particular clauses in the headquarter agreements, references to national law. This can include particular matters such as vacations, probationary periods, social security and other matters about which the organization has no desire to produce a complex regime and prefers to apply, as a mirror image, the local labour law. The governing principles of immunity explained above, indicate that this free selection of applicable law in certain matters, does not mean or imply a renunciation of jurisdictional immunity as a whole.

Codifying and doctrinal bodies of international law such as the ILI - International Law Institute - have recognized this practice between international organizations, their employees, and the host States. The Oslo Articles of the ILI collect the previously explained principles, including a) the notion that the selection of the applicable law is a matter of free choice between the or-

45 REINISCH, August. Contracts between International Organizations and Private Law Persons. Max Planck. Encyclopedia of Public International Law, v. 7, p. 754, 2006 ganization and the employee b) that the applicable law can include both the constitutive instruments of the organization, its regulations and if decided by the parties, references to national law without waiving immunity, and c) in the presence of jurisdictional immunity, the necessity of a body of dispute resolution.

\section{The Proper Law of the Contract}

Article 2

1. To facilitate the settlement of difficulties which may arise in connection with the contracts under consideration, it is desirable that the parties expressly specify the source, national or international, from which the proper law of the contract is to be derived.

2. The parties may expressly refer to a combination of several sources.

Article 3
Article 6
In so far as it constitutes the proper law of the
contract, the law of the organization shall be
considered as including the constitutive instrument,
any other rules governing the organization and
the practice established by the latter, these sources
being supplemented by the general principles of
law. ${ }^{46}$

While international case law has recognized that international organizations are not subject to the application of the labour law of the host State, in some cases, both international ${ }^{47}$ and national tribunals have found an obligation that is correlative to the concession of that jurisdictional immunity. This is found in the establishment of an adequate mechanism for the resolution of labour disputes within the organization, which would allow staff and officials to exercise their right to defense and access to justice ${ }^{48}$ inside the bodies or courts of the organizations, given the impossibility of recourse to the national court system. 
This concept was considered in the United States Federal case law as early as 1980, in the case Broadbent $v$. Organization of American States, in which the United States Federal Court of Appeals (D.C Cir.) held that submitting a labour dispute between an organization and its employees to the legislation and courts of a State was improper since national courts are unsuited for these kinds of disputes and are not the correct forum to resolve a private dispute that applies the special labour regime created by the organization. This was sufficient reason to not waive the immunity of the organization.

At first sight, disputes of this sort could be referred to municipal tribunals. The organization normally possesses immunity, but immunity can be waived. However, the special nature of the law governing employment in international organizations, closely linked as it is with delicate questions of administrative policy, makes municipal tribunals totally unsuited to deal with it. It would be like an English court trying to judge a dispute between the French Government and one of its officials. Courts in all countries usually refuse to handle questions of foreign public law, and, in the same way, a number of municipal courts have held themselves incompetent to judge claims brought by international civil servants against the organizations which employ them, not on the grounds of immunity, but on the grounds of the special law applicable.

There is therefore a vacuum which needs to be filled by the organizations themselves. The creation of an independent body, empowered to make binding decisions in legal disputes between an organization and its staff, is by no means an altruistic gesture from the organization's point of view; without it, officials might suffer from a sense of injustice which would impair the smooth running of the Secretariat.

The court notes that the OAS, like most international organizations, has established elaborate internal grievance machinery.

We hold that the relationship of an international organization with its internal administrative staff is noncommercial, and, absent waiver, activities defining or arising out of that relationship may not be the basis of an action against the organization regardless of whether international organizations enjoy absolute or restrictive immunity. ${ }^{49}$

Additionally, the Legal Yearbook of the United Nations has compiled cases, including a semi disclosed "Note Verbale" of 2012, in which the organization makes it clear that the exemption of "commercial acts",

49 Broadbent v. Organization of Am. States, 628 F.2d 27 (D.C. Cir. 1980) https:// casetext.com/case/broadbent-v-organization-of-amstates which constitutes customary law for diplomatic immunity (iure gestionis against iure imperii) is not applicable to the labour relations entertained by a United Nations Agency and is employees because the immunity in that field is functiona ${ }^{50}$ and "treaty based", meaning that jurisdictional immunity cannot be waived on these matters or unilaterally raised by national courts.

The Legal Counsel notes further that, in their submissions to the Court of [City], the claimants appear to be arguing a concept of immunity generally applied to sovereign states. The Legal Counsel wishes to point out that the concepts of jurisdictional immunities of states and the privileges and immunities of international organizations have a different nature and origin. The jurisdictional immunities of states are a part of customary international law that has evolved through the years and recently was codified in the United Nations Convention on Jurisdictional Immunities of States and their Property, 2004. Under customary international law, when a state acts as a private person in a commercial context (jure gestionis), it is not immune from the jurisdiction of the state in which it is acting in that capacity. In such a case, since the state is acting outside of its role as a sovereign power, the immunity does not apply.

Unlike the case with sovereign states, the privileges and immunities of the United Nations are of a treaty law nature and, as explained above, originated in the United Nations Charter and the General Convention. The exception to state immunity in situations where the state is undertaking commercial activities is not provided for under the United Nations Charter or the General Convention with respect to the United Nations.

Instead, pursuant to article VIII, section 29 of the General Convention, the Organization shall make provisions for appropriate modes of settlement of, inter alia, "disputes arising out of contracts or other disputes of a private law nature to which the United Nations is a party." Accordingly, there is no "commercial activity" exception under the General Convention that would be applicable with respect to the United Nations.

In this regard, the Legal Counsel wishes to note that the claimants in the above proceedings are therefore not without recourse. In accordance with article VIII, section 29 of the General Convention, disputes arising out of or in connection with the contracts may be subject to an appropriate mode of settlement by the Organization. Based on the foregoing, the Legal Counsel respectfully requests the Government of [State] to promptly take all necessary steps to ensure full respect for the privileges and immunities of the United Nations 50 SINGER, Michael. Jurisdictional Immunity of International
Organizations: Human Rights and Functional Necessity Concerns.
Vanderbilt Journal of International Law, v. 36, p. 53, 1995. 
in [State], in accordance with its obligations under international law. As a courtesy, a copy of this Note Verbale will also be sent to the Labour

Section of the Court of [State].

[...] 20 November $2012^{51}$

The contemporary leading case regarding the applicable labour law in private relations between a international organization and individuals, the scope of immunity in labour disputes and its relationship with the rights of the applicants, is acknowledged to be Waite and Kennedy v. Germany from the European Court of Human Rights. In this case British citizens instituted procedures before the German Courts against a local headquarter of the European Space Agency based in Germany, which under its Constitutive Agreement, had full jurisdictional immunity.

The application claimed damages for the wrongful procedure in their dismissal and requested that German labour law was to be applied to the organization.

The German courts, despite criticizing the dismissal procedure, enforced the jurisdictional immunity of the organization. Accordingly, the applicants chose to bring an action against Germany before the European Commission of Human Rights, arguing that the decision of the German national courts, violated their right to access to justice.

The European Court of Human Rights studied whether the immunity could had been waived by national courts when facing labour disputes and if the existence of a special labour law regime created by the international organization and its jurisdictional immunity upheld the standards of the European Convention.

62. The Committee of Staff Representatives of the Coordinated Organisations in their written comments (see paragraph 7 above) considered that the statutory provisions concerning immunity had to be interpreted so as to satisfy the fundamental rights under Article $6 \$$ 1 of the Convention.

63. Like the Commission, the Court points out that the attribution of privileges and immunities to international organisations is an essential means of ensuring the proper functioning of such organisations free from unilateral interference by individual governments.

\footnotetext{
51 https://legal.un.org/unjuridicalyearbook/pdfs/english/by_volume/2012/chpVI.pdf
}

The immunity from jurisdiction commonly accorded by States to international organisations under the organisations' constituent instruments or supplementary agreements is a long-standing practice established in the interest of the good working of these organisations. The importance of this practice is enhanced by a trend towards extending and strengthening international cooperation in all domains of modern society.

Against this background, the Court finds that the rule of immunity from jurisdiction, which the German courts applied to ESA in the present case, has a legitimate objective.

64. As to the issue of proportionality, the Court must assess the contested limitation placed on Article 6 in the light of the particular circumstances of the case.

65. The Government submitted that the limitation was proportionate to the objective of enabling international organisations to perform their functions efficiently. With regard to ESA, they considered that the detailed system of legal protection provided under the ESA Convention concerning disputes brought by staff and under Annex I in respect of other disputes satisfied the standards set in the Convention. In their view, Article $6 \int 1$ required a judicial body, but not necessarily a national court. The remedies available to the applicants were an appeal to the ESA Appeals Board if they wished to assert contractual rights, their years of membership of the ESA staff and their integration into the operation of ESA. According to the Government, the applicants were also left with other possibilities, such as claiming compensation from the foreign firm which had hired them out.

66. The Commission in substance agreed with the Government that in private-law disputes involving ESA, judicial or equivalent review could be obtained, albeit in procedures adapted to the special features of an international organisation and therefore different from the remedies available under domestic law. ${ }^{52}$

The ECtHR recognized the right of international organizations under their constitutive agreements to create their own labour law, and that pursuant to jurisdictional immunity, the organization was not bound to apply national labour law unless there was an exception

\footnotetext{
52 Waite and Kennedy v Germany, Merits, App No 26083/94, ECHR 1999-I https://iilj.org/wp-content/uploads/2016/08/ Waite-and-Kennedy-v.-Germany.pdf
} 
to immunity in this matter agreed in the treaties. Since the application was against a State, the ECtHR concluded that the German courts, by upholding the immunity of the organization, did not violate the applicants' right to access to justice, given that this immunity was backed by other means for the applicants to exercise their rights.

72. The Court shares the Commission's conclusion that, bearing in mind the legitimate aim of immunities of international organisations (see paragraph 63 above), the test of proportionality cannot be applied in such a way as to compel an international organisation to submit itself to national litigation in relation to employment conditions prescribed under national labour law. To read Article $6 ₫ 1$ of the Convention and its guarantee of access to court as necessarily requiring the application of national legislation in such matters would, in the Court's view, thwart the proper functioning of international organisations and run counter to the current trend towards extending and strengthening international cooperation.

73. In view of all these circumstances, the Court finds that, in giving effect to the immunity from jurisdiction of ESA on the basis of section 20(2) of the Courts Act, the German courts did not exceed their margin of appreciation. Taking into account in particular the alternative means of legal process available to the applicants, it cannot be said that the limitation on their access to the German courts with regard to ESA impaired the essence of their "right to a court" or was disproportionate for the purposes of Article $6 \$ 1$ of the Convention.

74. Accordingly, there has been no violation of that provision. ${ }^{53}$

The Waite case has received positive reception both from national courts ${ }^{54}$ and regional bodies, strengthening the acceptance of the principle that the proportionality between jurisdictional immunity and the right to defense is preserved if there is an adequate mechanism for internal dispute resolution used by the organization to provide a timely response to the requests of its employees.

Certain States like Belgium ${ }^{55}$ have gone beyond Waite and have decided to exempt the immunity of international organizations if they do not have, or do not activate or properly design this internal mechanism in order to resolve such disputes. This cannot be conside-

\footnotetext{
53 Waite and Kennedy v Germany, Merits, App No 26083/94, ECHR 1999-I https://iilj.org/wp-content/uploads/2016/08/ Waite-and-Kennedy-v.-Germany.pdf

${ }^{54}$ NOLLKAEMPER, André, et al. (ed.) International law in domestic courts: a casebook. USA: Oxford University Press, 2019.

${ }^{55}$ DE BRABANDERE, Eric. Belgian Courts and the Immunity of International Organizations. International Organizations Law Review, v. 10, n. 2, p. 464-504, 2014.
}

red a universal trend or a new customary rule, since this behavior arises from the State's obligation under the European Convention Art 6, as was argued in the cases Lutchmaya v. General Secretariat of African, Caribbean and Pacific Group of States, Brussels Labor Court, March 4, 2003, Journal des Tribunaux, 2003 and Siedler v. Western European Union, Appeal Judgment, JT 2004, 617, ILDC 53 (BE 2003), 17th September 2003, Belgium; Brussels; Labor Court of Appeal; 4th Chamber). For example, in the Siedler case, the Belgian Courts studied whether the levels of independence of the internal dispute resolution mechanism of the international organization upheld ECtHR standards and concluded that if the body is not independent, the immunity can be waived. This was, yet again, in a particular application of the European Convention, and leaves several questions regarding the breach of the treaty by the State, open.

\begin{abstract}
"The mode of designation-by an intergovernmental committee - and the short term of the mandate - two years - of the members of the commission were to be taken into account as well. These features of the internal appeals commission involved the risk that the members would be closely tied to the organization, thereby lacking independence [my emphasis]." ${ }^{56}$
\end{abstract}

On a more regional level, the 2018 OAS Guidelines on International Organizations by the Interamerican Judicial Committee have incorporated the Waite standard from the ECtHR and made clear as a practice for Latin American States and international organizations in the region that a natural counterpart for that functional immunity, is the ability of the organization ${ }^{57}$ to resolve labour disputes internally:

Guideline 6.

Characteristics of dispute resolution mechanisms

The dispute settlement mechanisms established by international organizations to

resolving private law disputes should be adequate and effective.

\section{Rapporteur's Notes}

The European Court of Human Rights in its case Waite and Kennedy v. Germany15 has established that immunity depends on the availability of adequate and effective remedies. To maintain

\footnotetext{
56 Belgian Court of Cassation, Western European Union v Siedler, Appeal Judgment Cass No S 040129 F (21 December 2009)

57 BERENSON, William M. Squaring the Concept of Immunity with the Fundamental Right to a Fair Trial: The Case of OAS. World Bank Legal Review, v. 3, p. 133, 2012.
} 
immunity the European Court has indicated three requirements:

(i) immunity must not restrict or reduce the right to due process;

(ii) the limitations on immunity must pursue a legitimate purpose;

(iii) there is a reasonable relationship of proportionality between the means used and the end accomplished.

The functional nature of immunities makes it necessary to preserve the right of access to justice for individuals. Therefore, it is not enough that there is an obligation to establish dispute resolution mechanisms. These Mechanisms should be adequate and effective.

Additionally, the principles of independence, transparency, professionalism, decentralization, Legality and due process should govern such mechanisms. Finally, the organization must disseminate its mechanisms duly among staff, in order to avoid ignorance of them. ${ }^{58}$

The number of international organizations with internal dispute resolution mechanism makes it difficult to present a study of every single example in the present article. It is illustrative, however, to present some treaty clauses or staff regulations that develop the dispute resolution mechanisms for labour disputes that international organizations have designed, so as to demonstrate the way in which these guarantee the due process of the employees and fulfill the goal of jurisdictional immunity from labour courts without undermining the rights of the claimants. For instance, the Staff Regulations and Rules of the United Nations (2018) from rules 11.0 to 11.5 contemplate a mechanism that involves informal resolution, the participation of an ombudsman, a formal complaint before a tribunal and a formal appeal before an appeals tribunal.

Rule 11.1

\section{Informal resolution}

(a) A staff member who considers that his or her contract of employment or terms of appointment have been violated is encouraged to attempt to have the matter resolved informally. To that end, a staff member who wishes to pursue informal channels should approach the Office of the Ombudsman without delay, without prejudice to the right to pursue the matter formally in

58 OAS. Informe del comité jurídico interamericano. Inmunidades de las organizaciones internacionales, (93o período ordinario de sesiones OEA/Ser. Q 6 al 16 de agosto 2018) CJI/doc.554/18 rev.2 Rio de Janeiro, Brasil 16 agosto 2018 accordance with the provisions of the present chapter.

(b) Both the staff member and the Secretary-General may initiate informal resolution, including mediation, of the issues involved at any time before or after the staff member chooses to pursue the matter formally.

(c) The conduct of informal resolution by the Office of the Ombudsman, including mediation, may result in the extension of the deadlines applicable to management evaluation and to the filing of an application with the United Nations Dispute Tribunal, as specified in staff rules 11.2 (c) and (d) and 11.4 (c) below.

(d) An application shall not be receivable by the United Nations Dispute Tribunal if the dispute arising from a contested decision has been resolved by an agreement reached through mediation. However, a staff member may submit an application directly with the Dispute Tribunal to enforce the implementation of an agreement reached through mediation within 90 calendar days of the deadline for implementation as specified in the mediation agreement or, when the mediation agreement is silent on the matter, within 90 calendar days of the thirtieth calendar day from the date on which the agreement was signed. ${ }^{59}$

The World Bank Tribunal Statute also contemplates mediation mechanisms for employment disputes to be exhausted between the staff member and the corresponding organ before a formal complaint can be entertained by the tribunal in a more judicial manner. Several other examples can be reviewed in the Staff regulations or resolutions that constitute the tribunals of the organizations, such as the Article 270 of the Treaty on the Functioning of the European Union (TFEU) ${ }^{60}$, the ILO Administrative tribunal ${ }^{61}$, the NATO Administrative Tribunal ${ }^{62}$ or the OECD Administrative Tribunal ${ }^{63}$

1. The Tribunal shall hear and pass judgment upon any application by which a member of the staff of the Bank Group alleges non-observance of the contract of employment or terms of appointment of such staff member. The words "contract of employment" and "terms of appointment" include all pertinent regulations and rules in force at the time of alleged non-observance including the provisions of the Staff Retirement Plan.

59 https://hr.un.org/content/staff-rules-112

${ }^{60}$ https:// eur-lex.europa.eu/legal-content/en / ALL/?uri=CELEX\%3A12012E\%2FTXT

${ }^{61}$ https://www.ilo.org/tribunal/about-us/WCMS_249194/lang-en/index.htm

62 https://www.nato.int/nato_static_fl2014/assets/pdf/ pdf_2015_09/20150902_150902-cpr-en.pdf

63 https://www.oecd.org/careers/Staff_Rules_en.pdf 
2. No such application shall be admissible, except under exceptional circumstances as decided by the Tribunal, unless:

(i) the applicant has exhausted all other remedies available within the Bank Group, except if the applicant and the respondent institution have agreed to submit the application directly to the Tribunal; and

(ii) the application is filed within one hundred and twenty days after the latest of the following:

(a) the occurrence of the event giving rise to the application;

(b) receipt of notice, after the applicant has exhausted all other remedies available within the Bank Group, that the relief asked for or recommended will not be granted; or

(c) receipt of notice that the relief asked for or recommended will be granted, if such relief shall not have been granted within thirty days after receipt of such notice.

3. For the purposes of this Statute:

the expression "member of the staff" means any current or former member of the staff of the Bank Group, any person who is entitled to claim upon a right of a member of the staff as a personal representative or by reason of the staff member's death, and any person designated or otherwise entitled to receive a payment under any provision of the Staff Retirement Plan. ${ }^{64}$

\section{Remarks on the Colombian case law regarding immunities of the international organizations in labour disputes: judicial misapplication of the exemptions emanating from diplomatic immunity.}

Finally, this article concludes with an analysis of a particularly complex case of reception and misinterpretation of the principles governing diplomatic immunity and the immunity of international organizations in labour disputes. At the Constitutional Court of Colom$\mathrm{bia}^{65}$, the debate on the jurisdictional immunity of international organizations and diplomatic missions has

\footnotetext{
${ }^{64}$ https://tribunal.worldbank.org/statute

65 ABELLO-GALVIS, Ricardo, ARÉVALO RAMÍREZ, Walter. La inmunidad de las organizaciones internacionales y de sus funcionarios cuando son nacionales del Estado sede. Diferencias con la inmunidad diplomática y experiencias de la jurisprudencia internacional y colombiana. Anuario Mexicano de Derecho Internacional, v. XXI, 2021.
}

taken a spotlight through its two main judicial areas of jurisdiction.

The first, namely the "abstract control of constitutionality (automatic judicial review)" ${ }^{\prime 66}$, occurs when the Constitutional Court, in the face of the laws approving a treaty prior to its entry into force, within the ratification process, or, in the face of public actions of unconstitutionality (judicial review actions) against those laws approving the treaty ${ }^{67}$. Under these procedures, the Constitutional Court has analyzed the constitutionality of different instruments that contain precepts of the two aforementioned types of immunities: treaties constituting international organizations, and treaties related to diplomatic immunity.

The second of these areas of jurisdiction under which the Constitutional Court of Colombia has entertained cases related to immunity, is called "specific control" (control concreto ${ }^{68}$ ), where citizens by means of individual suit actions or applications can claim against public or private subjects before any judge to guarantee their fundamental constitutional rights against a specific damage. Under this type of jurisdiction, there have been numerous cases against diplomatic missions and international organizations claiming protection from human rights violations, including those arrising out of labour disputes.

Recurrently, the Colombian case law as it will be shown below, has adequately recognized the rationale behind the immunity of international organizations and their functional relationship with the object and purpose of the organization, considering that such immunity is both necessary for the organization and does not constitute a violation of the sovereignty of the host State. It has, however, erroneously transferred the customary limitations and exemptions of the immunity of

${ }^{66}$ ARÉVALO RAMÍREZ, Walter; GARCÍA LÓPEZ, Luisa Fernanda. La interpretación constitucional y sus métodos en el sistema jurídico norteamericano, una interacción entre lo político y lo jurídico: Teorías y casos de estudio. Ius et Praxis, v. 24, n. 2, p. 393-430, 2018.

67 ABELLO GALVIS, Ricardo. La Corte Constitucional y el derecho internacional Los tratados y el control previo de constitucionalidad 1992-2004. Estudios Socio-Jurídicos, v. 7, n. 1, p. 305-382, 2005. ${ }^{68}$ GARCÍA-MATAMOROS, Laura Victoria, ARÉVALORAMÍREZ, Walter. Dos décadas de debates entre la Constitución de 1991 y el derecho internacional: El control constitucional de los tratados, las enmiendas constitucionales y la oposición a sentencias de tribunales internacionales. De la constitución de 1991 a la realidad: Debates políticos, jurídicos, territoriales e internacionales. Universidad del Rosario, 2015. p. 347-376. 
diplomatic missions, such as not granting immunity to nationals, and excluding or limiting it in commercial or labour relations, to the immunity of international organizations, contrary to its conventional scope.

A relevant starting point for a case law analysis, is the Colombian Constitutional Court (CCC) judgment C-254 of 2003, where the Constitutional Court recognizes that the immunity of international organizations is the product of what is agreed in its Constitutive Treaty and that functional immunity is governed by the agreement by the States Parties. The CCC held that an immunity agreement on jurisdiction does not per se violate national sovereignty or the principle of equality (of individuals before the law), This position was originally advanced in CCC judgment C-203 of 1995, a case involving the judicial review of the law approving the treaty of the Agreement Establishing the Multilateral Investment Guarantee Agency (MIGA). Extended extracts from the decision in Spanish can be found in the footnote ${ }^{69}$.

${ }_{69}$ CCC Judgment C-254/03. Para comenzar es necesario advertir que la jurisprudencia constitucional ha admitido la introducción de cláusulas de inmunidad en los tratados internacionales como reconocimiento de que las mismas son medios "que han existido para asegurar la independencia de los representantes diplomáticos, y que se han extendido a las organizaciones internacionales, a sus bienes y funcionarios también para asegurar la autonomía de esas entidades." [9] - Adujo en este contexto que la institución de la inmunidad no esper se contraria al ordenamiento jurídico.

Lo mismo subrayó cuando revisó la exequibilidad de la Ley 464 de 1998 que aprobó el "Convenio Internacional de las Maderas Tropicales", suscrito en Ginebra en 1994. El artículo 17 de dicha Convención establece un sistema de inmunidades y privilegios similar al que contiene la Convención sobre asistencia en caso de accidente nuclear o emergencia radiológica. El numeral $3^{\circ}$ de dicho articulo señala que "La organización [Internacional de Maderas Tropicales] podrá concertar con uno o más países acuerdos, que habrán de ser aprobados por el Consejo, sobre las facultades, privilegios e inmunidades que sean necesarios para el debido funcionamiento del presente Convenio."

En relación con esta disposición, que faculta a la Organización internacional para establecer regimenes de inmunidades a favor de sus miembros, la Corte adujo que las inmunidades y privilegios conferidos a miembros de organismos internacionales se ajustan a la Carta Política siempre y cuando estén encaminadas a la "defensa, igualdad y soberanía del organismo de derecho internacional de que se trate y de los Estados que acuerdan conceder dichas prerrogativas [10] ." La Corte agregó que de no hacerse tal salvedad, "[b]ajo el manto de buenas intenciones patrocinadas por el Convenio, que la Corte respeta y alienta, (...) cláusulas como la analizada pueden constituirse en el germen de tratamientos diferenciales y privilegiados que den cabida a injusticias y desequilibrios."

Dicha posición refrendó lo sostenido por la Corte en la Sentencia C-137 de 1996 a propósito de la revisión constitucional de la Ley 208 de 1995, por la cual se aprobó el "Estatuto del Centro Internacional de Ingeniería Genética y Biotecnologia", hecho en Madrid en 1983.

Al igual que la Convención sobre el manejo de maderas tropicales, el Estatuto del Centro Internacional de Ingeniería Genética y Biotecnología cuenta con una norma destinada a regular los privilegios e inmunidades de los miembros del Centro. El artículo 13 del Estatuto prescribe, entre otras cosas, que "6. Los
Erroneously, in CCC Judgment C-788 of 2011 regarding the Agreement on Cooperation and Regime of Privileges and Immunities between the International Organization for Migrations and the government of the Republic of Colombia, the Court, through a misinterpretation of the nature of diplomatic immunity and its distinction with the immunity of international organizations, extended the customary limitations on immunity inherent to diplomatic missions to international organizations, while disregarding the principles explained above and their treaty based nature.

The areas in which the judgment unduly extends the limitations to diplomatic immunity to the regime of international organizations include: i) labour matters, in which diplomatic missions and international organizations when hiring nationals would be subject to national labour law and national social security law ii) commercial transactions, "private contracts" and inheritance law, where it indicated that members of the diplomatic corps do not have immunity for acts outside their function of representing the State and must submit to civil jurisdiction, as well as for "commercial acts", an exception which, as we have seen above, cannot be applied to the international organization since the difference between acts iure gestionis and iure imperii do not apply. Regarding administrative and criminal matters, the CCC held that the immunity must be interpreted close to the constitutive agreement, allowing affected citizens by such immunity to sue the State, a position also concurred by the Council of State. ${ }^{70}$

This Corporation has defined the following limitations on the immunity of agents of foreign States and international law organizations that are in the national territory in the guardianship headquarters and in matters of constitutionality control: 1 . The labor jurisdiction. In judgment T-932 of 2010, the Court analyzed the case of a citizen in favor of whom the Diplomatic Mission of the Embassy of the Bolivarian Republic of

funcionarios del Centro gozarán de las prerrogativas e inmunidades que dispone el Artículo $V$ de la Convención sobre Prerrogativas e Inmunidades de las $\mathrm{Na}$ ciones Unidas", que "5. Los representantes de los Miembros gozarán de las prerrogativas e inmunidades que dispone el Articulo IV de la Convención sobre Prerrogativas e Inmunidades de las Naciones Unidas", y que "7. Los expertos del Centro gozarán de las mismas prerrogativas e inmunidades estipuladas para los funcionarios del Centro en el párrafo 6 que antecede."

Frente a dichas disposiciones la Corte sostuvo que las inmunidades conferidas a los miembros de un organismo internacional son concesiones ofrecidas con fundamento en disposiciones de derecho internacional que no quebrantan por si mismas el concepto de soberania nacional.

${ }^{70}$ CCC Judgment C-788 of 2011. 
Venezuela in Colombia stopped making contributions to the Pension System. In order to resolve the specific case, in the general considerations of the ruling, the Ninth Review Chamber reached three main conclusions: (i) progressively, international law has recognized that States and international organizations have restricted immunity in labor matters, In other words, it has accepted that diplomatic missions and supranational organizations can be called to trial by local courts "when labor and benefit rights of nationals and permanent residents of the national territory are compromised [...]."; (ii) when a foreign State enters into an employment contract with a Colombian national, it must submit unrestrictedly to internal labor regulations, which is why "a sending State cannot claim immunity for claims derived from the employment contract or the performance of relations labor. "; ."; and (iii) the conclusion of employment contracts with Colombian nationals obliges diplomatic missions and supranational organizations to assume the risk of old age, "through the affiliation of the worker to the Social Security Institute or even to other social welfare entities that cover such a risk. "In line with the conclusions noted, when verifying that the plaintiff could go before the labor judges to obtain the protection of her claims, and in view of the need to adopt urgent and urgent measures to guarantee the protection of her fundamental rights to the minimum vital and safety social, the Court granted the protection filed as a transitory mechanism and ordered the Head of the Diplomatic Mission of the Embassy of the Bolivarian Republic of Venezuela in Colombia to pay the plaintiff "the sum equivalent to a legal monthly minimum wage in force in accordance with Colombian regulations, as a provisional old-age pension and until the ordinary labor courts resolve the substantive dispute regarding labor rights that the plaintiff will raise. "Thus, it can be concluded that the protection action is appropriate to obtain the protection of the fundamental rights to the vital minimum, to work and to social security of those who have provided their services to a diplomatic mission or an international organization, when the employer has omitted to comply with the duty to make the corresponding contributions to the Pension System.

Judgment C-788 of 2011 which deepens the difficulty of its approach to the immunity of international organizations shows that the Constitutional Court took as a generalizable parameter, the limitations to immunity agreed in the "Convention on Special Missions of the United Nations", a treaty that was analyzed by the Court in judgment C-315 of 2004 and that is repeatedly cited in decisions such as C-788 of 2011. The limitations on immunity agreed to in that treaty cannot be extended to all international organizations and their constituent conventions, but the Colombian Constitutional Court seems to take it as a guide to understanding immunity itself. ${ }^{71}$

This argument regarding the exemptions, waivers and limitations to the immunity of international organizations derived from diplomatic immunity in judgment C-788 of 2011, is replicated in judgment C-267 of 2014 on the Agreement between Colombia and the Organization for the Prohibition of Chemical Weapons regarding its Privileges and Immunities (OPCW). ${ }^{72}$

71 CCC Judgment C-788 of 2011. Mediante la sentencia C-315 de 2004, la Sala Plena de esta Corte declaró la constitucionalidad de "La Convención sobre las Misiones Especiales" de las Naciones Unidas -abierta a la firma en Nueva York el 16 de diciembre 1969-, así como de la Ley aprobatoria 824 de 2003. De acuerdo con el artículo 31 de dicha Convención, los representantes de un Estado y los miembros del personal diplomático gozan de inmunidad civil y administrativa, salvo en estos casos: "a) una acción real sobre bienes inmuebles particulares radicados en el territorio del Estado receptor, a menos que la persona de que se trate los posea por cuenta del Estado que envía para los fines de la misión; | | b) una acción sucesoria en la que la persona de que se trate figure, a título privado y no en nombre del Estado que envia, como ejecutor testamentario, administrador, heredero o legatario; || c) una acción referente a cualquier actividad profesional o comercial ejercida por la persona de que se trate en el Estado receptor, fuera de sus funciones oficiales; $[y]||$ d) una acción por daños resultante de un accidente ocasionado por un vebiculo utilizado fuera de las funciones oficiales de la persona de que se trate". Con fundamento en las disposiciones anteriores, en la citada sentencia, luego de reiterar que el principio de inmunidad de jurisdicción restringida no contradice la Constitución pues no vulnera por si mismo el principio de igualdad, la Corte afirmó que los articulos que abordan el tema contenidos en la Convención deben ser entendidos de conformidad con (i) la jurisprudencia del Consejo de Estado en lo concerniente a la jurisdicción administrativa, y (ii) los demás artículos de la misma Convención que se refieren a las obligaciones generales que deben satisfacer los integrantes de una misión diplomática. [...]. 3. La jurisdicción penal. La citada Convención sobre las Misiones Especiales de las Naciones Unidas, incorporada al ordenamiento jurídico interno por la Ley 824 de 2003, también señala en su articulo 31 que los representantes de un Estado y los miembros del personal diplomático gozan de inmunidad penal en el Estado receptor.".

${ }^{72}$ CCC Judgment C-267 of 2014:

5.2.1 El tema del principio de inmunidad de jurisdicción frente a la procedibilidad de la acción de tutela contra organismos internacionales para obtener la protección del derecho fundamental de petición, únicamente ha sido abordado por la Corte en tres sentencias, por lo que en seguida se hará una breve referencia a cada una de ellas:

5.2.1.1 En la sentencia T-883 de 2005, la Corte estudió las sentencias proferidas en el trámite de la acción de tutela instaurada por un ciudadano contra el Programa de las Naciones Unidas para el Desarrollo (PNUD), por considerar que dicho programa vulneró sus derechos fundamentales de petición y honra. [...] Para resolver el caso concreto, en las consideraciones generales de la sentencia, la Sala Quinta de Revisión explicó que en el ámbito constitucional, el principio de inmunidad de jurisdicción debe atender a varios aspectos. En primer lugar, señaló que el principio en comento "no puede entenderse como una babilitación que am- 
In the field of "acción de tutela" (a specific control or writ for protection of constitutional rights) (Also called "Recurso de Amparo" in Latin America), in cases involving a request to international organizations to appear before national authorities, the Constitutional Court has held different positions. On the one hand, it reinforces the exceptions to immunity already admitted in its other previously cited judgments, while on the other, it creates an unclear position regarding the duty to appear before national authorities and courts when an international organization is summoned.

The Constitutional Court in judgment T-611 of 2011, compiles cases in which international organizations based in their territory have been called to respond to requests from authorities or citizens and compares it with the customary obligation of diplomatic missions to respond to these requests when the summons involves a labour dispute with a national.

In its dictum, the Constitutional Court mentions that international organizations have to present themselves before national authorities in private disputes, or disputes involving labour law and disputes involving fundamental rights, to the extent that such appearance does not affect its object and purpose.

This last test, although more favorable than a total waiver of immunity in the matter by national courts, does not correspond to the precepts already described,

para conductas arbitrarias y que pueden resultar lesivas de derechos consagrados y protegidos por el ordenamiento interno", pues la inmunidad otorgada por el Estado colombiano a un organismo de derecho internacional, solo puede ser considerada constitucional si responde "a la necesidad de asegurar la independencia y neutralidad de las labores que desarrolle el sujeto de derecho internacional correspondiente." En segundo lugar, sostuvo que dada la tendencia actual seguida por la mayoría de Estados de conceder inmunidad restringida a autoridades extranjeras, "es posible que el texto mismo del tratado o convenio respectivo, establezca el mecanismo a través del cual se pueden solucionar las controversias en las que se vean involucrados sujetos que gozan de inmunidades reconocidas por los Estados, con lo que se garantiza, además, la protección efectiva de los derechos de los individuos[25]." Y en tercer lugar, concluyó que ante la necesidad de garantizar la protección de los derechos vulnerados, particularmente del derecho al acceso a la administración de justicia, "en los casos en los que la protección del derecho exija la realización de determinada conducta por el sujeto que goza de inmunidad, podría el afectado solicitar al Estado colombiano que supla la actuación del funcionario u organización respectiva, en el evento en que ello fuere posible, toda vez que por esa vía se garantizarian los derechos de la persona, respetando la inmunidad que fue reconocida por el Estado."

Con fundamento en lo anterior, la Corte negó el amparo de los derechos fundamentales invocados, al estimar que era el Ministerio de Hacienda y Crédito Público en calidad de organismo ejecutor del Proyecto para la Modernización de la Administración Financiera Pública, y no el PNUD, la entidad encargada de dar respuesta a la petición presentada por el actor. namely, that international law contemplates for full functional-jurisdictional immunity.

Another decision in which the CCC proceeded to limit the immunity of international organizations, by identifying a "duty" to appear before national authorities, is judgment T-093 of 2012, which although reaffirms the immunity from jurisdiction and execution, affirms that Colombia has been part of the historical process in which diplomatic immunities are being transferred to the sphere of international organizations.

It is at this point in which the constitutional court erroneously transfers the exceptions emanating from diplomatic custom to diplomatic immunity.

4.2.1. The Colombian State has recognized that the immunities and prerogatives granted by the country to officials of international organizations or diplomatic representatives of other States, in guarantee of the need to ensure the independence and neutrality of the work carried out by the corresponding international law subject, harmonize with the provisions of the Political Constitution. It is mainly about the United Nations Convention on Privileges and Immunities of February 13, 1946, ratified by Colombia through Law 62 of 1973 , an instrument of which Colombia is a party and is bound since it has not denounced it, nor has it conditioned or reserved any of its provisions.

4.2.2. Immunity, for the case at hand, constitutes, then, a procedural rule that operates as an exception and which has two fundamental manifestations: (i) immunity from jurisdiction as such, which refers to the incompetence of national judges to judge certain subjects of international law, which may be other States or international organizations and (ii) immunity from execution, which prevents a certain judicial decision from being made effective, in the event that the procedure against the subject of international law is have carried out [10]. In this regard, the Court has expressed:

[...] from the principle of sovereignty, independence and equality of the States, a rule of public international law is derived, recognized by custom and international conventions by virtue of which the agents and property of foreign States must be immune from the coercive action of the public authorities of the host States. This principle was extended to the officials and assets of international agencies or centers in order to guarantee, fundamentally, the independence of said organizations in the fulfillment of their functions, wherever, by virtue of an international agreement, they operate. ${ }^{73}$.

\footnotetext{
73 CCC Judgment T-093 of 2012
} 
In sum, the reception and development of the immunity principles explained above by the Colombian jurisdiction is contradictory. Colombian constitutional jurisprudence, does not correctly identify the nature, scopes or sources that govern diplomatic and international organizations, generating confusion about the restrictions that are admissible to each one.

\section{Conclusion}

As a concluding remark, it is important to say that even if functional immunity and jurisdictional immunity of international organizations are concepts that tend to be clear in doctrine, casebooks and theory, their reception by national courts or their scope under the scrutiny of international tribunals is still evolving in the field of labour disputes. The differences with diplomatic immunity from the point of view of sources of international law are clear but both international and national jurisdictions still struggle with the applicable law to labour relations between the organizations and individuals, thus undermining the immunity as conceived in the constitutive instrument of international organizations, usually by applying exemptions arising from customary international law in the field of diplomatic immunity, to international organizations, where such exemptions may have not been contemplated in their constitutive treaties.

Regarding the misconception about immunities in the Colombian case law, it is urgent to recover the separation by national courts of the two types of immunity and their scope in the Colombian jurisdiction, so as to avoid that this limitation to the immunity of international organizations keeps leading to arbitrariness in the decisions of the judges and national authorities. These violations and limitations on the immunity of international organizations as the International Court of Justice has recognized in the 1949 advisory opinion "Reparation for injuries suffered in the service of the United Nations", can generate a right to the international organization, as a subject of international law, to invoke international responsibility against the State and claim reparation for the damage through all the diplomatic and jurisdictional mechanisms at its disposal.

Finally, the duty to constitute an internal dispute resolution mechanism for labour disputes inside the inter- national organizations that can correctly apply the staff regulations and the special labour regime devised by the organization, as a counterpart for the recognition of the immunity, is a development that is still in process of reception both by regional bodies and national tribunals, constituting the last frontier where the immunity of the organization can be upheld or waived, wrongfully and unilaterally, by national courts.

\section{References}

ABELLO GALVIS, Ricardo. La Corte Constitucional y el derecho internacional Los tratados y el control previo de constitucionalidad 1992-2004. Estudios Socio-Jurídicos, v. 7, n. 1, p. 305-382, 2005.

ABELLO-GALVIS, Ricardo. La Costumbre como Fuente de Derecho Internacional: una Caja de Pandora Imposible de Cerrar. Derecho internacional: varias visiones, un maestro. Liber amicorum en homenaje a Marco Gerardo Monroy Cabra. 2015. p. 3-28. Ed. Universidad del Rosario.

ABELLO-GALVIS, Ricardo; ARÉVALO RAMÍREZ, Walter. La inmunidad de las organizaciones internacionales y de sus funcionarios cuando son nacionales del Estado sede. Diferencias con la inmunidad diplomática y experiencias de la jurisprudencia internacional y colombiana. Anuario Mexicano de Derecho Internacional, v. XXI, 2021.

ABELLO-GALVIS, Ricardo; ARÉVALO RAMÍREZ, Walter. La inmunidad de las organizaciones internacionales y de sus funcionarios cuando son nacionales del Estado sede. Diferencias con la inmunidad diplomática y experiencias de la jurisprudencia internacional y colombiana. Anuario Mexicano de Derecho Internacional, v. XXI, 2021.

ARAÚJO KALLÁS, Fernanda. A imunidade de jurisdição das Organizações Internacionais face ao direito de acesso à justiça. Revista de Direito Internacional - Brazilian Journal of International Law, v. 13, n. 3, 2016.

ARÉVALO RAMÍREZ, Walter; GARCÍA LÓPEZ, Luisa Fernanda. La interpretación constitucional y sus métodos en el sistema jurídico norteamericano, una interacción entre lo político y lo jurídico: Teorías y casos de estudio. Ius et Praxis, v. 24, n. 2, p. 393-430, 2018. 
ARÉVALO-RAMÍREZ, Walter. Organizaciones Internacionales Manual de derecho internacional público. Fundamentos, tribunales internacionales y casos de estudio. $2 \mathrm{da}$ Ed. España: Tirant Lo Blanch Editorial, 2020.

BARKER, J. Craig; WARBRICK, Colin; MCGOLDRICK, Dominic. State Immunity, Diplomatic Immunity and Act of State: A Triple Protection against Legal Action?. The International and Comparative Law Quarterly, v. 47, n. 4, p. 950-958, 1998.

BAXTER, Richard R. Multilateral Treaties as Evidence of Customary International Law. British Yearbook of International Law, v. 41, p. 275, 1965.

BELGIUM. Brussels Appeals Court. Manderlier v. United Nations and Belgian State: Decision of 15 September 1969

BELGIUM. Brussels Appeals Court. Manderlier v. United Nations and Belgian State: Decision of 15 September 1969 United Nations Juridical Yeabook 1969.

BELGIUM. Brussels Appeals Court. Manderlier v. United Nations and Belgian State: Decision of 15 September 1969 United Nations Juridical Yeabook 1969.

BELGIUM. Siedler v. Western European Union, Belgian Labor Court of Appeals, Brussels, September 17, 2003, Journal des Tribunaux 2004, 617.

BELGIUM. Western European Union v Siedler, Belgian Court of Cassation, 21 December 2009. Paras. 4855.

BERENSON, William M. Squaring the Concept of Immunity with the Fundamental Right to a Fair Trial: The Case of OAS. World Bank Legal Review, v. 3, p. 133, 2012.

BROWN, Jonathan. Diplomatic immunity: State practice under the Vienna convention on diplomatic relations. International and Comparative Law Quarterly, v. 37, p. 53, 1988.

CANADA. SCC Amaratunga v. Northwest Atlantic Fisheries Organization, 2013 SCC 66, [2013] 3 S.C.R. 866 https://scc-csc.lexum.com/scc-csc/scc-csc/en/ item/13364/index.do

CCC Judgment C-254 of 2003.

CCC Judgment C-267 of 2014.

CCC Judgment C-788 of 2011.

CCC Judgment T-093 of 2012.
COUNCIL OF EUROPE. Resolution 1979 (2014)1 Accountability of international organizations for human rights violations Parliamentary Assembly. Council of Europe.

DE BRABANDERE, Eric. Belgian Courts and the Immunity of International Organizations. International Organizations Law Review, v. 10, n. 2, p. 464-504, 2014.

DENZA, Eileen. Diplomatic law: commentary on the Vienna convention on diplomatic relations. Oxford University Press, 2016.

EVANS, Malcolm. International Law. Fifth Edition. Oxford, 2018.

EVANS, Malcolm. International Law. Second Edition. Oxford, 2006.

GARCÍA-MATAMOROS, Laura Victoria, ARÉVALO-RAMÍREZ, Walter. Dos décadas de debates entre la Constitución de 1991 y el derecho internacional: El control constitucional de los tratados, las enmiendas constitucionales y la oposición a sentencias de tribunales internacionales. De la constitución de 1991 a la realidad: Debates políticos, jurídicos, territoriales e internacionales. Universidad del Rosario, 2015. p. 347-376.

GODIO, Leopoldo. Evolución, actualidad y tendencias en materia de privilegios e inmunidades de organismos internacionales. Revista RECORDIP, v. 1, n. 2, 2011.

I.C.J Effect of Awards of Compensation Made by the U.N. Administrative Tribunal, Advisory Opinion, 1954 I.C.J. 47 (July 13)

I.C.J. Applicability of Article VI, Section 22, of the Convention on the Privileges and Immunities of the United Nations, Advisory Opinion, I.C.J. Reports 1989, p. 177.

I.C.J. Diference Relating to Immunity from Legal Process of a Special Rapporteur of the Commission on Human Rights, Advisory Opinion, I.C.J. Reports 1999, p. 62

INSTITUT DE DROIT INTERNATIONAL. Session of Oslo - 1977 Contracts Concluded by International Organizations with Private Persons (Fourth Commission, Rapporteur: Mr Nicolas Valticos.

LIMA, Lucas Carlos. "The OAS Inter-American Juridical Committee and the Codification of Regional International Law." Brazilian Journal of International Law, v. 16, p. 292, 2019. 
MACKENZIE, David Clark. A world beyond borders: An introduction to the history of international organizations. University of Toronto Press, 2010.

MACLEAN, Robert Joseph-Blaise; ARÉVALO RAMÍREZ, Walter. The Expulsion of Resident Colombian Nationals during the Colombia-Venezuela Border Dispute: An "Under the Radar" Case for Diplomatic Protection of Human Rights?. Vniversitas, v. 68, p. 138, 2019.

MILLER, Anthony. Privileges and immunities of United Nations officials. International Organizations Law Review, v.4, n. 2, p. 169-257, 2008.

MULLER, A. Sam. International organizations and their host states: aspects of their legal relationship. Martinus Nijhoff Publishers, 1995.

NETHERLANDS. X et al. v.European School Munich I63 the Bavarian appellate Administrative Court, USIran Claims Tribunal v AS, 96 ILR 321, 329 (Netherlands Supreme Court, 1985)

NOLLKAEMPER, André, et al. (ed.) International law in domestic courts: a casebook. USA: Oxford University Press, 2019.

OAS Informe del comité jurídico interamericano. Inmunidades de las organizaciones internacionales, (93o período ordinario de sesiones OEA/Ser. Q 6 al 16 de agosto 2018) CJI/doc.554/18 rev.2 Rio de Janeiro, Brasil. 16 agosto 2018.

OKEKE, Edward Chukwuemeke. Jurisdictional immunities of states and international organizations. Oxford University Press, 2018.

QUINTANA ARANGUREN, Juan José; GUZMÁN CARRASCO, Gonzalo. De espaldas al derecho internacional: Colombia y la inmunidad de jurisdicción de los Estados. International Law: Revista Colombiana de Derecho Internacional, v. 8, p. 53-102, 2006.

REINISCH, August. Contracts between International Organizations and Private Law Persons. Max Planck Encyclopedia of Public International Law, v. 7, p. 754, 2006.

REINISCH, August. International organizations before national courts. No. 10. Cambridge University Press, 2000.

REINISCH, August; WEBER, Ulf Andreas. In the shadow of Waite and Kennedy-The jurisdictional immunity of international organizations, the individual's right of access to the courts and administrative tribunals as alternative means of dispute settlement. International Organizations. Law Review, v. 1, p. 59, 2004.

RIOS, Greta L., FLAHERTY Edward. International Organization Reform of Impunity-Immunity is the Problem. ILSA Journal of International \& Comparative Law, v. 16, p. 433, 2009.

RYNGAERT, Cedric, PENNINGS Frans. Jurisdictional immunity and infringement of fundamental labor rights. International Labor Rights Case Law, v. 3, n. 3, p. 327-332, 2017.

RYNGAERT, Cedric. Immunities of International Organizations Before Domestic Courts: Reflections on the Collective Labour Case Against the European Patent Organization. Netherlands Yearbook of International Law, 2015. TMC Asser Press, The Hague, 2016. 393-408.

SARMIENTO LAMUS, Andrés. ¿Es la "Paradoja Baxter" una verdadera paradoja? La práctica de los Estados, entre la formación del derecho internacional consuetudinario y la interpretación de tratados". In: ABELLO-GALVIS, Ricardo; ARÉVALO RAMÍREZ, Walter. (ed.) Derecho Internacional Público, Derecho Internacional de la Inversión Extranjera. Universidad del Rosario. 2019. p $.57-75$.

SINGER, Michael. Jurisdictional Immunity of International Organizations: Human Rights and Functional Necessity Concerns. Vanderbilt Journal of International Law, v. 36, p. 53, 1995.

STEWART, David P. The UN Convention on Jurisdictional Immunities of States and Their Property. The American Journal of International Law, v. 99,n. 1, p. 194211, 2005.

TESFAGABIR, Kibrom. The state of functional immunity of international organizations and their officials and why it should be streamlined. Chinese Journal of International Law, v. 10, n. 1, p. 97-128, 2011.

VAN ERT, Gib, ALLEN, Greg J. ROBB, Rebecca. Canadian Cases in Public International Law in 2013. Canadian Yearbook of International Law, v. 51, p. 535, 2013.

WEBB, Philippa. The Immunity of States, Diplomats and International Organizations in Employment Disputes: The New Human Rights Dilemma?. European Journal of International Law, v. 27, n. 3, p. 745-767, 2016. 
WOJCIKIEWICZ ALMEIDA, Paula. L'affaire des immunités juridictionnelles de l'Etat (Allemagne c. Italie): la Cour Internationale de Justice à contre-sens de l'évolution du droit international. ACDI-Anuario Colombiano de Derecho Internacional, v. 11, p. 21-70, 2018.

WOOD, Michael. Do international organizations enjoy immunity under customary international law?. Immunity of International Organizations. Brill Nijhoff, 2015.

WOOD, Michael. International Organizations and $\mathrm{Cu}-$ stomary International Law. Vanderbilt journal of transnational law, v. 48, n. 3, p. 609, 2015. 
Para publicar na Revista de Direito Internacional, acesse o endereço eletrônico www.rdi.uniceub.br ou www.brazilianjournal.org.

Observe as normas de publicação, para facilitar e agilizar o trabalho de edição. 